Document downloaded from:

http://hdl.handle.net/10251/45265

This paper must be cited as:

García-Arias, A.; Francés, F.; Morales De La Cruz, MV.; Real Llanderal, J.; Vallés Morán, FJ.; Garófano-Gómez, V.; Martinez-Capel, F. (2014). Riparian evapotranspiration modelling: model description and implementation for predicting vegetation spatial distribution in semi-arid environments. Ecohydrology. 7(2):659-677. doi:10.1002/eco.1387.

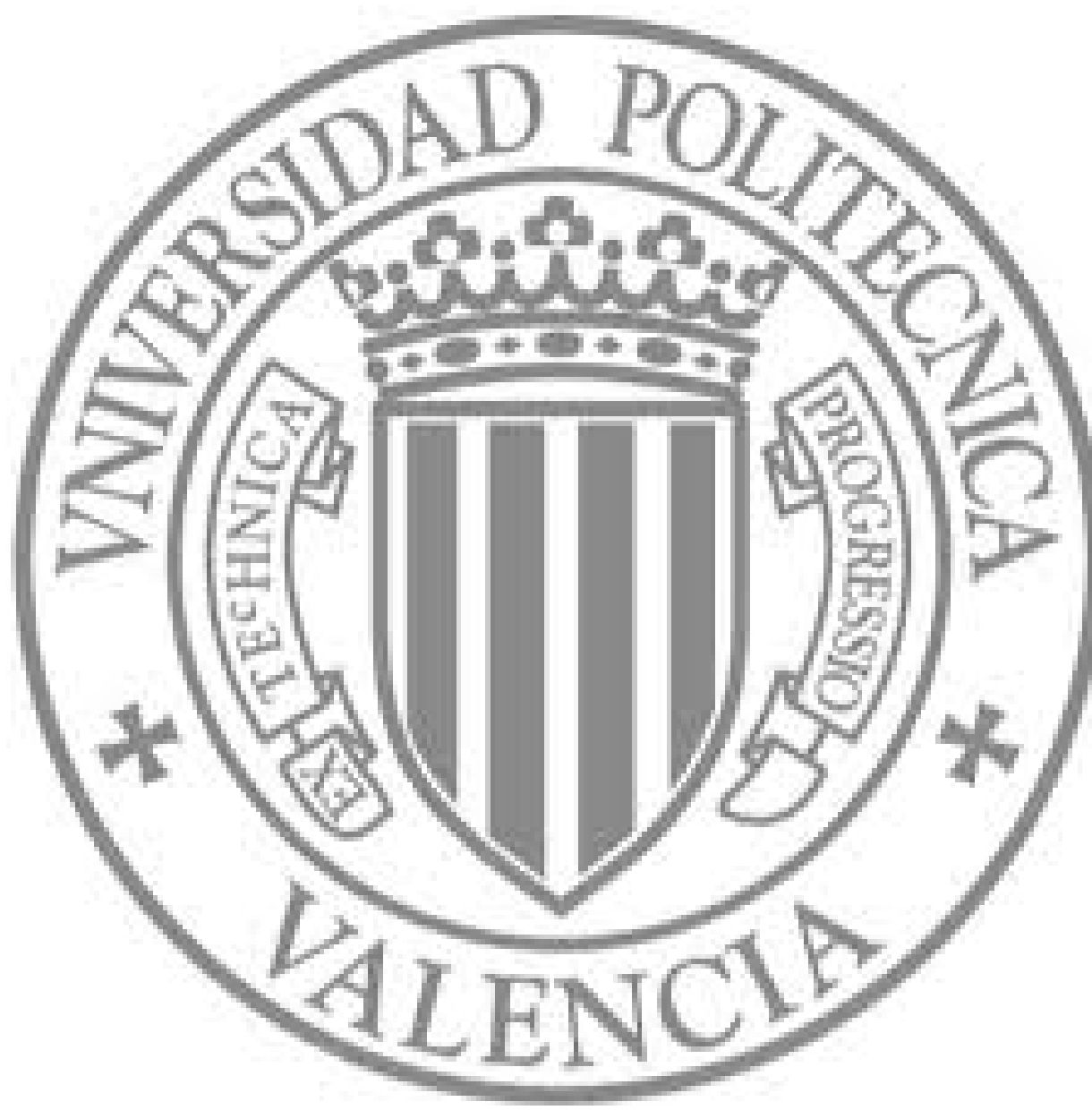

The final publication is available at

http://dx.doi.org/10.1002/eco.1387

Copyright Wiley 
This is a pre-copyedited, author-produced PDF version following peer review of the article: García-Arias A., Francés F., Morales-de la Cruz M., Real J., Vallés-Morán F., Martínez-Capel F., Garófano-Gómez V. 2014. Riparian evapotranspiration modelling: model description and implementation for predicting vegetation spatial distribution in semi-arid environments. Ecohydrology, 7: 659-677. DOI: 10.1002/eco.1387, which has been published in definitive publisher-authenticated form at http://onlinelibrary.wiley.com/doi/10.1002/eco.1387/abstract

Article published online 1 MAY 2013 by John Wiley \& Sons, Ltd. All rights reserved. All further use of this material other than for personal research is subject to permission from the publisher.

\title{
RIPARIAN EVAPOTRANSPIRATION MODELLING: MODEL DESCRIPTION AND IMPLEMENTATION FOR PREDICTING VEGETATION SPATIAL DISTRIBUTION IN SEMI-ARID ENVIRONMENTS
}

\author{
García-Arias A. ${ }^{1}$, Francés F. ${ }^{1}$, Morales-de la Cruz M. ${ }^{1^{*}}$, Real J. ${ }^{1}$, Vallés-Morán \\ F. ${ }^{1}$, Garófano-Gómez V. ${ }^{2}$, Martínez-Capel F. ${ }^{2}$ \\ ${ }^{1}$ Research Institute of Water and Environmental Engineering, Universitat Politècnica de \\ València, Camino de Vera s/n, 46022, Valencia, Spain. \\ * Nowadays in Specific Cabinet on Water, Vicepresidency of the Republic, 26 Ave. 10-76 z.7 KJ \\ I, Guatemala. \\ ${ }^{2}$ Research Institute for Integrated Management of Coastal Areas, Universitat Politècnica de \\ València, C/ Paranimf, 1, 46730 Grao de Gandia (Valencia), Spain.
}

\begin{abstract}
Biotic and abiotic interactions between the riparian zone and the river determine relevant hydrological processes and exert control over riparian and bordering upland vegetation types. Vegetation growth and development are mainly controlled by water availability on semi-arid regions so the closeness to the river yields a moisture gradient which clearly determines the boundaries between exuberant riparian zone and semi-arid upland. A mathematical model named RibAV is presented. Its conceptualization is based on the main worldwide ecosystem modelling approaches and field expertise. The implementation of RibAV that is proposed in this paper allows the simulation of the vegetation functional types distribution in riparian zones. An evapotranspiration index $\left(E_{i d x}\right)$ obtained through RibAV is used as criterion for long-term plant absence/presence prediction. Two permanent river reaches of semi-arid Mediterranean basins, the Terde reach (Mijares River, Spain) and the Lorcha reach (Serpis River, Spain), have been selected as case studies for the evaluation of the model performance. Several criteria based on the confusion matrix were used to analyze the efficiency of RibAV on the prediction of plant distribution. The model outstanding performance to establish riparian vegetation types distribution and the limit between this zone and the bordering upland is demonstrated in this paper; the strength of the $E_{i d x}$ to classify plant functional types in riparian semi-arid environments is additionally proved.
\end{abstract}


KEY WORDS Soil moisture; evapotranspiration modelling; riparian vegetation; spatial distribution; functional types

\section{INTRODUCTION}

Of particular interest are the riparian ecosystems from an ecohydrological point of view. The importance of these ecosystems lies in their continuous interaction with the river. Riparian ecosystems have important regulation capabilities on the hydrological processes, including different degrees of water balance control, retention of sediments and regulation of nutrients, etc. In this context, the riparian vegetation exerts a main role in the hydrological feedback mechanisms between the river-soil-atmosphere systems (Lowrance et al., 1998; Scott et al., 2000; Tabacchi, 2000; Rodriguez-Iturbe et al., 2001). On the other hand, the hydrological regime of the river is responsible for the riparian ecosystem maintenance (Malanson, 1993; Lambers et al., 1998; Richards et al., 2002; Vidon and Hill, 2004; Naiman, 2005; Merrit et al., 2010). Due to this connection, a better knowledge of the interactions between the river and the riparian forest is essential to manage properly the conservation and restoration initiatives (Stromberg, 2001; Glenz, 2005). For management purposes, mathematical models are important tools that allow systematic analyses of river ecosystems. The European Water Framework Directive (WFD 2000/60/EC) pointed out the importance that have the development of new advanced tools for helping to achieve the good ecological status of river related ecosystems by predicting the effects caused by changes of the ecosystem driving forces (Perona et al., 2009).

Floods have been traditionally considered as an essential driving force of disturbance for the riparian ecosystems, as they force the vegetation succession cycle and the biotic factors resettlement (e.g., Azami et al., 2004; Choi et al., 2005; Glenz, 2005; Tabacchi, 2005; Ocampo et al., 2006; Wen et al., 2010, Benjankar et al., 2011, García-Arias et al., submitted for publication). Nevertheless, in semi-arid riparian zones where the annual flood period is short, the droughts can be harder than the flood itself and the occurrence of scarce water availability become a limiting factor that is responsible for the vegetation hydrological stress (Porporato et al., 2001; Rodríguez-Iturbe and Porporato, 2004). The riparian vegetation distribution is, in consequence, mainly driven by the soil moisture and the water table elevation, which are determined by the hydrological regime of the river (Richards et al., 1996; Hughes et al., 2003).

Under these conditions, the water balance is conditioned by the riparian forest and, in consequence, there has been a growing interest in the riparian vegetation evapotranspiration modelling (e.g. Altier et al., 2002; Baird and Maddock III, 2005; Mac Nish et al., 2000; Serrat-Capdevila et al., 2011). However, to our knowledge, the previous models have overlooked that the evapotranspiration of the riparian plants occurs from the two possible sources of water availability, the static storage and the saturated zone, being used often simultaneously.

The primary objective in this paper is to provide the conceptualization of a new model called RibAV. This mathematical model has been performed from an ecohydrological point of view to predict the riparian vegetation evapotranspiration in semi-arid environments, considering both sources of 
water availability. The model, taking as reference previous studies (Scott et al., 2000; Porporato et al., 2001; Altier et al., 2002; Baird and Maddock III, 2005), considers the water availability as the main driving force that determines the vegetation comfort. For different plant functional types (PFTs), and considering their distinct adaptation and response mechanisms to collect the available water from the saturated and the unsaturated zones, RibAV calculates rates of actual evapotranspiration. The definition of the parameters in RibAV is based in the architecture of several biotic and abiotic models developed for the riparian zone all over the world (Welsch, 1991; Stromberg et al., 1993, 1996; Bendix, 1994; Lowrance et al., 1998; Brinson and Verhoeven, 1999; Brooks et al., 2000; Snyder and Williams, 2000; Horton et al., 2001; Altier et al., 2002; Sparovek et al., 2002; Maddock III and Baird, 2003; Baird and Maddock III, 2005; Lamontagne et al., 2005; Lite et al., 2005; Stave et al., 2005; Webb and Leake, 2006; Merrit et al., 2010).

Aditionally, the present paper extends the use of the RibAV model by proposing an index called $E_{i d x}$ that relates the actual evapotranspiration to the potential evapotranspiration of the PFTs. The maximum evapotranspiration rates are frequently used as a measure of plant growth and productivity (Quevedo and Francés 2008), and as an indicator of the optimum environmental conditions for different vegetation types in semi-arid zones (Porporato et al., 2001). Indirectly, the temporal series of evapotranspiration rates can be considered as both, a measure of water use (Laio et al., 2001; Lautz, 2008), and plant resistance to saturation in the root zone (Baird and Maddock III, 2005). Given this, in order to predict the spatial distribution of different PFTs in the riparian zone, and the limit between the riparian zone and the neighbouring upland zone through the RibAV model, the $E_{i d x}$ is used. For the distribution modelling, it has been established that the PFT with a higher value of $E_{i d x}$, is the one which has a better response/adaptation to the variable environmental conditions of each unit area, compared to the other PFTs analyzed under the same conditions and during the same period. The proposed hypothesis considers the static comparison and hierarchical organization of the PFTs respective $E_{i d x}$ values as a good criterion for long-term zonation prediction. The second part of the paper includes the RibAV model implementation, through the $E_{i d x}$ as criterion for vegetation zonation prediction, in two semi-arid Mediterranean rivers reaches in order to validate this last hypothesis.

\section{THE RIBAV MODEL}

\section{General description}

The RibAV model has been designed to simulate water availability and evapotranspiration near the river, especially in the riparian zone. This water availability from the saturated and unsaturated zones of the soil depends on the local climate and it is strongly controlled by the river flow regime and the vegetation adaptation mechanisms. RibAV has based its approach on the concept of soil-plant-atmosphere continuum and consequently it requires the inclusion of vegetation and soil parameters to allow the representation of its conceptual framework. In RibAV, vegetation is considered fixed in time but variable in space. The theory of PFTs is applied, considering the taxonomical 
vegetation characteristics, in order to parameterize the vegetation from the model point of view.

The RibAV model is distributed in space, using a regular division in cells. Due to the strong sensitivity to vertical distances and lengths, altitude differences must be limited. Consequently, cell sizes used in RibAV are recommended to be lower than $10 \mathrm{~m}$. To capture properly the evapotranspiration dynamics, the model uses daily temporal discretization.

The general conceptualization of RibAV is shown in Figure 1 . Its conceptualization is oriented to a proper, but simple as possible, modelling of the evapotranspiration. For each cell, the actual evapotranspiration $(E)$ is computed as the sum of the evapotranspiration from the unsaturated zone, represented by the static storage (Figure 1), and the direct transpiration from the saturated zone. The static storage represents the capillary water availability for evapotranspiration in the upper part of the soil. Therefore, it is limited by the soil surface elevation $\left(Z_{s}\right)$, the effective root depth $\left(D_{e}\right)$ and the moistures corresponding to wilting point $\left(\theta_{w p}\right)$ and field capacity $\left(\theta_{f c}\right)$. The saturated zone is defined by the water table elevation $\left(Z_{w t}\right)$, which is variable in time and which is only controlled by the river water level in RibAV. Considering this hypothesis, it is not needed to establish the water balance in the saturated zone.

As shown in Figure 1, the possible flows between the static storage and the saturated zone are the unsaturated vertical flow and the hydraulic lift by roots $(U)$. The first one can be a downward percolation $(P e)$ or an upward capillary water flow (Cwf). Pe is not simulated explicitly in RibAV, because is included in the excess water $(X)$ of the static storage and there is no need of water balance in the saturated zone. $X$ also includes the surface runoff $(S r)$.

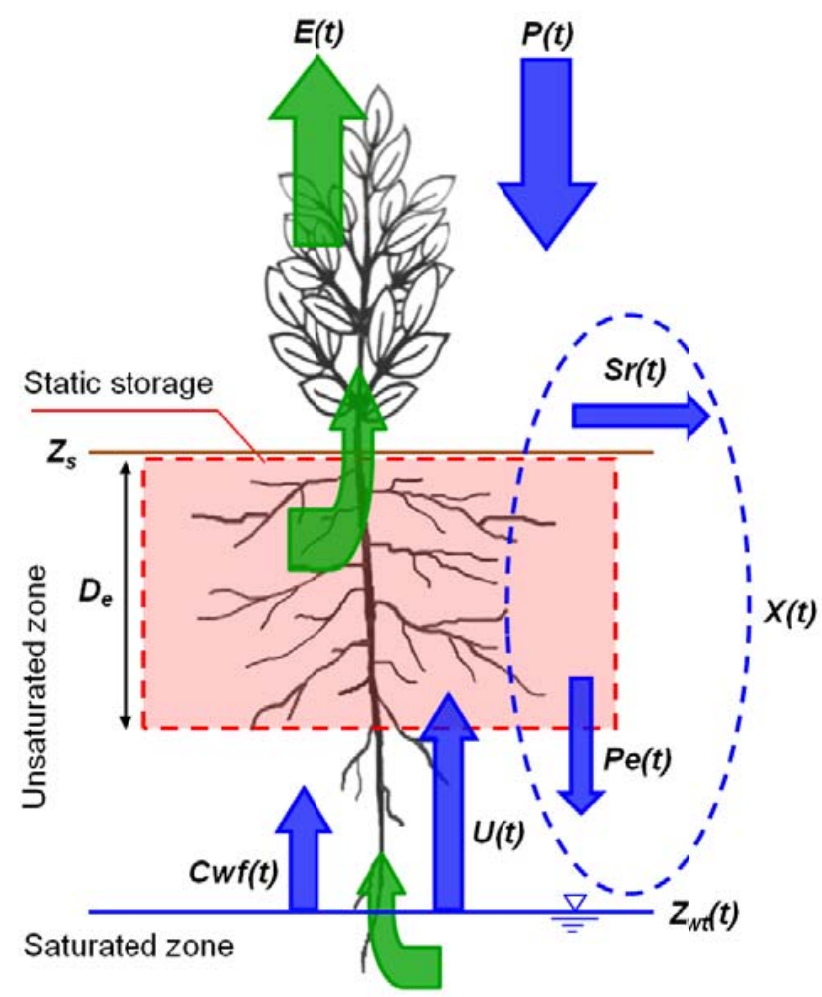

Figure 1. General conceptualization for one cell in the RibAV model. Arrows represent water fluxes in and out of the system; the actual evapotranspiration is represented with green arrows, considering as sources the saturated and unsaturated zones of the soil profile. 


\section{Soil parameters}

Soil parameters are used in RibAV for the definition of the static water storage. These parameters, described below, are specific for each type of soil present in the study site.

The moisture content at field capacity $\left(\theta_{f c}\right)$ can be measured in the laboratory or calculated from the soil-water retention curve for any of the different pressures cited by various authors as reference for field capacity $\left(\Psi_{f_{c}}\right): 33 \mathrm{kPa}$ (Wild, 1992; Kramer and Boyer, 1995; Dingman, 2002), $15 \mathrm{kPa}$ (Larcher, 2003) or in the range between 202.65 and $303.98 \mathrm{kPa}$ (Guymon, 1994). The latter methodology is also applicable to obtain the bubbling pressure $\left(\Psi_{b}\right)$, considering the soil textural class and its physical properties (Rawls et al., 1993).

The hydraulic conductivity of the saturated soil $\left(K_{s}\right)$ can be measured in laboratory or can be obtained from the soil textural class using pedotransfer functions (Saxton et al., 1986).

In this work, we have used the Campbell's soil-water retention curve (Campbell, 1974), and the corresponding equation for the hydraulic conductivity of the unsaturated soil $\left(K_{u}\right)$, given by:

$$
\begin{aligned}
\psi(\mathrm{t}) & =\frac{\psi_{b}}{\left(\frac{H(t)}{D_{e} \cdot \phi}\right)^{1 / \lambda}} \\
\mathrm{K}_{\mathrm{u}}(\mathrm{t}) & =\mathrm{K}_{\mathrm{s}} \cdot\left(\frac{\psi_{b}}{\psi(t)}\right)^{3 \lambda+2}
\end{aligned}
$$

where $\psi$ is the capillary pressure of the soil, $\Psi_{b}$ is the bubbling pressure, $\lambda$ is the pore size distribution index, $H$ is the water content in the static storage, $\Phi$ is the soil porosity, and $D_{e}$ is the effective root depth, a vegetation parameter.

The pore size distribution index $(\lambda)$ is defined by physical properties related to the soil textural class (Rawls et al., 1993), while the soil porosity $(\Phi)$ can be derived by this methodology or can be measured in the laboratory.

The maximum depth to consider upward capillary flow from the water table to the static storage $\left(D_{c}\right)$ can be established through reference values that can be found in Brouwer et al. (1985). It has to be noticed that the upward capillary flow is considered cancelled when the water table is below this parameter. $D_{c}$ has to be referred to the soil surface elevation $\left(Z_{s}\right)$ in order to obtain the minimum elevation to consider capillary rise from the water table $\left(Z_{c}\right)$.

\section{Vegetation parameters}

The plant coverage fraction $(C v)$ is related to the ratio between the soil covered by the perpendicular projection of the vegetation canopy and the total area of soil occupied by each functional type. It is defined as a fixed value between 1 and 0.25, and its establishment can be done through field observation, geographic information systems, aerial photography or literature reported values (Causton, 1988; Bonham, 1989; Maddock III and Baird, 2003; Scott et al., 2003). 
Some plant specific pressure points are included as vegetation parameters. The optimum plant transpiration pressure $\left(\Psi^{*}\right)$ is defined as the pressure in the precise moment when the plant still has no water availability limitations. According to Eagleson (2002), this pressure corresponds to a value of $500 \mathrm{kPa}$. In the Ecohydrological vision of Porporato et al. (2001), this parameter is defined as the 'point of incipient stomata closure', and can correspond to pressures up to $3000 \mathrm{kPa}$ (Laio et al., 2001), but it depends on each plant adaptation to water scarcity. The wilting point pressure $\left(\Psi_{w p}\right)$ is considered as the pressure in the precise moment when the plant halts its transpiration. The value can be defined considering theoretical values reported by other authors in the range between 506.63 and $1519.90 \mathrm{kPa}$ (Guymon, 1994). Although many authors have agreed to consider a typical value of $1500 \mathrm{kPa}$ (e.g., Kramer and Boyer, 1995; Terradas, 2001), higher values as $3000 \mathrm{kPa}$ or $5.000 \mathrm{kPa}$ have been suggested for plants adapted to arid environments (Laio et al., 2001).

The model includes, in addition, three important parameters related to root depths. The maximum root depth $\left(D_{r}\right)$ defines the soil depth considered for presence of roots, while the effective root depth $\left(D_{e}\right)$ defines the soil depth considered for static storage. These parameters are based on field measurement or criteria according to expert databases or references (Canadell et al., 1996; Kellman and Roulet, 1990; Schulze et al., 1996; Schenk and Jackson 2002, 2005; Baird and Maddock III, 2005). The asphyxia root depth $\left(D_{a}\right)$ sets the maximum water table elevation tolerated by roots. It can be negative for submersion resistant plants, which are tolerant to water table elevations over the soil surface. The value can be established based on field observations, expert rules or background references (Snyder and Williams, 2000; Maddock III and Baird, 2003; Baird and Maddock III, 2005; Webb and Leake, 2006). Since RibAV defines the interaction of biotic and abiotic factors in a spatial context, it is necessary to refer the root depth parameters to the $Z_{s}$. In this sense, the following derived parameters are defined: the maximum root depth elevation $\left(Z_{r}\right)$, the effective root depth elevation $\left(Z_{e}\right)$, and finally the asphyxia by saturation root depth elevation $\left(Z_{a}\right)$.

Finally, two transpiration factors related to the water source are included. These parameters establish the capability and preference of the considered PFTs to transpire water from the static storage and/or the saturated zone. The first one is the transpiration factor from the unsaturated zone $\left(r_{u}\right)$ which take into consideration the root system located over $D_{e}$. The second is the transpiration factor from the saturated zone $\left(r_{s}\right)$ due to the part of the root system located under $Z_{w t}$. These parameters must assume values between 0 and 1 , being the higher values those which represent a higher use of specific water source for transpiration, and being able to add more than one (Cooper et al., 2006; Butler Jr. et al., 2007). Both parameters can be established by expert rules, taking as reference the relative density of roots in both zones of the soil, unsaturated and saturated, field observation or literature reported values (e.g., Sparks, 1995; Schaeffer and Williams, 1998; Mac Nish et al., 2000; Snyder and Williams, 2000; Horton et al., 2001; Hughes et al., 2003; Lambs, 2004; Lamontagne et al., 2005; Lite and Stromberg, 2005; Scott et al., 2006; David et al., 2007; Wen et al., 2010). 
The state variable in the RibAV model that represents the moisture in the upper part of the soil is the water content in the static storage. Therefore, it will be needed to convert capillary pressures into water contents. Thus, other derived parameters of the model are established by using the Campbell's equation (1), as the wilting point moisture $\left(\theta_{w p}\right)$, the optimum plant transpiration point moisture $\left(\theta^{*}\right)$, and the moisture content at field capacity $\left(\theta_{f c}\right)$.

The parameter $D_{e}$ allows relating these pressures to water contents. This is the case of the water content equivalent to the wilting point $\left(H_{w p}\right)$, the water content equivalent to the optimum plant transpiration point $\left(H^{*}\right)$, and the water content equivalent to field capacity $\left(H_{f c}\right)$, given by the multiplication of each specific moisture and $D_{e}$.

\section{Hydraulic and hydrometeorological inputs}

For computing the soil moisture in the unsaturated zone and the actual evapotranspiration, the RibAV model requires as input the daily meteorological series: precipitation $(P)$ and potential evapotranspiration $\left(E_{0}\right)$.

On the other hand, in this riparian model the hydrological regime determines the water-table fluctuations on the riparian zone. Instead of having a time series of $Z_{w t}$ maps, it is required as input the daily series of river flows (Q) and a set of water table elevation maps $\left(Z_{w t, j}\right)$ associated to reference flows $\left(Q_{j}\right)$. Thereby, the $Z_{w t}$ for each cell is estimated by interpolation of the reference $Z_{w t, j}$ maps:

$$
\mathrm{Z}_{\mathrm{wt}}(t)=\mathrm{Z}_{\mathrm{wt}, \mathrm{j}-1}+\left(\frac{Q(t)-Q_{j-1}}{Q_{j}-Q_{j-1}}\right) \cdot\left(Z_{w t, j}-Z_{w t, j-1}\right)
$$

where $Q$ is interpolated with the immediately higher and lower reference values, $Q_{j}$ and $Q_{j-1}$, and their corresponding reference water table elevations, $Z_{w t, j}$ and $Z_{w t, j-1}$.

\section{Water balance in the static storage}

The static storage represents the upper part of the soil that is unsaturated. Since the water content in this soil layer $(H)$ ranges between $H_{f c}$ and $H_{w p}$, water can be extracted from the static storage only by evapotranspiration. As it is represented in Figure 2, the water content at the end of day $t$ is given by the next balance equation:

$$
H(t)=\operatorname{Max} \mid \begin{aligned}
& I(t)+H(t-1)-E u(t) \\
& H_{w p}
\end{aligned}
$$

where I represents the water inputs to the static storage, and $E_{u}$ is the actual evapotranspiration from the unsaturated zone.

By adding the local precipitation, the contributions from the saturated zone and the excess water, I can be calculated:

$$
I(t)=P(t)+U(t)+C w f(t)-X(t)
$$




$$
X(t)=\operatorname{Max} \mid \begin{aligned}
& 0 \\
& P(t)+U(t)+C w f(t)-H_{f c}+H(t-1)
\end{aligned}
$$

where $U$ is the hydraulic lift or root water uptake, Cwf is the upward capillary water flow, $X$ is the excess or gravitational water, $P$ is the precipitation and $H_{f c}$ is the upper limit of $H$.

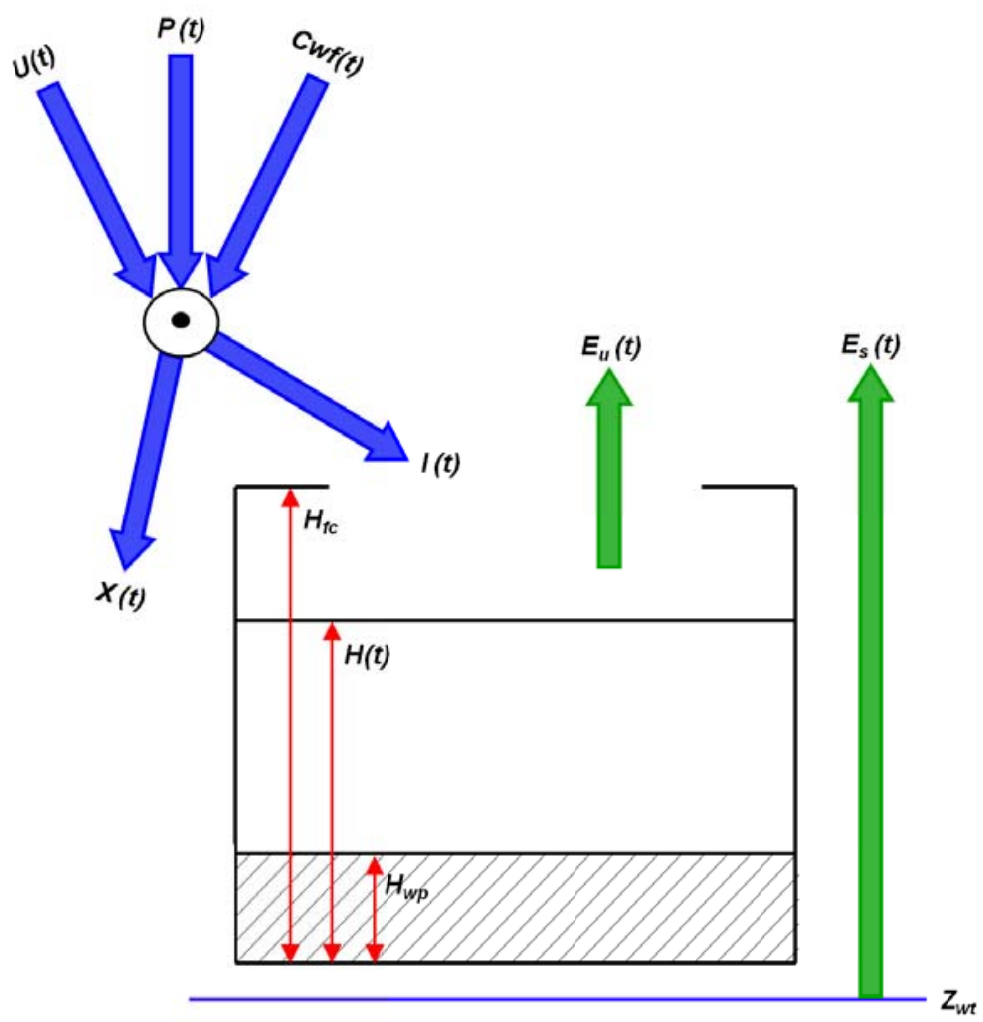

Figure 2. Tank conceptualization schema of the static storage (unsaturated upper soil) in RibAV. The input and output water fluxes are represented by blue and green thick arrows. Water contents are represented by red thin arrows. The specific meaning of the symbol representing each parameter can be found in the Appendix section.

\section{Water fluxes from the saturated zone}

The water fluxes from the saturated zone are basically two: the hydraulic lift $(U)$ and the upward capillary water flow (Cwf).

The modelling of the $U$, root water uptake from the saturated zone, is a remarkable novelty developed in RibAV. This approach is based in the research of Ryel et al. (2002) and takes into account some considerations proposed by Lee et al. (2005) and Zheng and Wang (2007). Following the approach proposed by Ryel et al. (2002), the hourly hydraulic lift between two layers of the soil 'i,j' $\left(q_{h r(i, j)}\right)$ can be defined as function of the maximum water conductivity in root-soil interface $(\mathrm{Cr})$, the difference between the capillary pressure of both layers of the soil $(\Delta \Psi)$, the relative water conductivity in root-soil interface $\left(C_{j}\right)$, the efficiency of the root conductivity expressed in terms of roots distribution in the soil $\left(F_{\text {root }}\right)$, and a factor of occurrence $\left(S_{t}\right)$ : 
$q_{h r(i, j)}=-C r \cdot \Delta \psi \cdot C_{j} \cdot\left(\frac{F_{\text {root }_{i}} \cdot F_{\text {root }_{j}}}{1-F_{\text {root }_{j}}}\right) \cdot S_{t}$

$S_{t}$ was considered to adopt the value 1 during the nighttime, since the hydraulic lift usually occurs during the night (e.g. Amenu and Kumar, 2008). Whereas RibAV has been designed for the daily scale, a corrector factor that corresponds to the number of night hours $\left(h_{n}\right)$ has been included. This nighttime can be approximated to 10 hours as reported by Ryel et al. (2002).

The parameter $F_{\text {root }}$ adopts values between 0 and 1 (Ryel et al., 2002). RibAV models the hydraulic lift from the water table to a unique layer, the static storage. In consequence, simplifying is possible by considering the relative density of roots in the saturated zone of the soil, which can be assumed as the vegetation parameter $r_{s}$, the transpiration factor from the saturated zone.

$C_{j}$ ranges between 0 and 1 , and follows an empirical relation with $\psi$ (Ryel et al., 2002; Zheng and Wang, 2007):

$$
C_{j}=\frac{1}{1+\left(\psi(t) / \psi_{50}\right)^{3.22}}
$$

where $\Psi_{50}$ is the midpoint saturation pressure that corresponds to a relative soil moisture of $50 \%$, and $\psi$ is the capillary pressure of the soil.

Moreover, Ryel et al. (2002) estimated the value of $\mathrm{Cr}$ as $0.97 \mathrm{~mm} \mathrm{MPa}^{-1} \mathrm{~h}^{-1}$, and this value has been consolidated in other studies (i.e. Zheng and Wang, 2007).

Taking these considerations into account, the calculation of $U$ in RibAV is proposed as follows when the water table elevation is connected to the root system during the night:

$$
U(t)=\operatorname{Max} \mid-C r \cdot h_{n} \cdot\left(\psi_{\mathrm{fc}}-\psi(t)\right) \cdot\left[\frac{1}{1+\left(\frac{\psi(t)}{\psi_{50}}\right)^{3.22}}\right] \cdot r_{s}
$$

where, for each unit area, $\mathrm{Cr}$ corresponds to $0.97 \mathrm{~mm} \mathrm{MPa}^{-1} \mathrm{~h}^{-1}, h_{n}$ corresponds to 10 hours of nighttime, $\Psi_{f c}$ is the field capacity point pressure, and $r_{s}$ corresponds to the value of the transpiration factor from the saturated zone.

On the other hand, in order to describe the Cwf in riparian zones, the Darcy's equation (Skaggs, 1978) is used, considering $K_{u}$ (the hydraulic conductivity of the unsaturated soil), which is calculated through the equation 2. There are two possible cases. Firstly, if $Z_{e}>Z_{w t}$, the upward capillary water flow from the saturated zone is given by: 


$$
C w f(t)=\operatorname{Max}|\operatorname{Min}| \begin{aligned}
& H_{f c}-H(t-1)-U(t) \\
& {\left[\left(\frac{-0.102 \cdot \psi(t)}{Z_{w t}(t)-Z_{e}}\right)-1\right] \cdot 24 K_{u}(t)}
\end{aligned}
$$

In this case, two values are required to be included as dimensional corrections, [0.102 $\mathrm{m}$ water column $\left.\mathrm{kPa} \mathrm{a}^{-1}\right]$ and $\left[24 \mathrm{~h} \mathrm{~d}^{-1}\right]$. In a second case when $Z_{w t} \geq Z_{e}$, it is assumed the hypothesis in which the upward capillary water flow is enough to fill the static storage tank up to field capacity. Then, Cwf is calculated with the following equation:

$$
C w f(t)=H_{f c}-H(t-1)-U(t)
$$

Finally, since the $Z_{c}$ threshold corresponds to the minimum elevation needed to be exceeded by the $Z_{w t}$ to allow capillary water rise, if $Z_{c} \geq Z_{w t}$ the $C w f$ is 0 .

\section{Actual evapotranspiration in the riparian zone}

In RibAV, the actual evapotranspiration $(E)$ is determined by the soil saturation, the roots connectivity with the water table (Maddock III and Baird, 2003; Baird and Maddock III, 2005), and the soil moisture content (Inamdar et al., 1999; Altier et al., 2002; Dahm et al., 2002). This is the reason why the actual evapotranspiration estimation in the RibAV model includes the evapotranspiration from the unsaturated upper part of the soil $\left(E_{u}\right)$ represented by the static storage, and the evapotranspiration from the saturated zone of the soil $\left(E_{s}\right)$ :

$$
E(t)=E_{u}(t)+E_{s}(t)
$$

In order to estimate $E, R i b A V$ starts from the potential evapotranspiration $\left(E_{0}\right)$, as the simplest and most traditional way to represent the energy availability and the atmospheric conditions in the process (Allen et al., 1998; Butler Jr. et al., 2007). As it has been explained before, the water source for the transpiration is defined by the vegetation factors that control the capacity and/or preference of water collecting from the static storage and/or the groundwater, $r_{u}$ and $r_{s}$.

The process extinction, evapotranspiration equal to cero, is simulated both when the water table and the root system are disconnected and when the upper part of the soil is saturated in an unbearable level for the plants. The first case is specific for the evapotranspiration from the saturated zone and is defined by the maximum root depth elevation. When the root system and the water table are not connected $\left(Z_{w t}<Z_{r}\right), E_{s}$ is 0 . The second case of evapotranspiration extinction considers flood duration, frequency, depth, and seasonality as critical factors for the riparian species composition and distribution (Brinson and Verhoeven, 1999; Tabacchi et al., 2005), since the soil saturation generates anaerobic conditions that affect the plant physiology. In order to include this effect in the model, the vegetation parameter asphyxia by saturation root depth elevation represents the maximum water table elevation from which the roots are not able to collect more water due to soil saturation. Thus, $E$ is 0 when the water table exceeds this critical elevation $\left(Z_{w t} \geq Z_{a}\right)$. 
There are two more possible cases considering the effective root depth elevation $\left(Z_{e}\right)$ threshold. The first case considers the water table between $Z_{a}$ and $Z_{e}$. In this case $\left(Z_{a}>Z_{w t} \geq Z_{e}\right)$ the evapotranspiration can be at potential rate, being the unsaturated evapotranspiration proportional to the relative water availability between $Z_{w t}$ and $Z_{a}$ :

$$
E_{u}(t)=r_{u} \cdot C v \cdot E_{0}(t) \cdot\left(1-\frac{Z_{w t}-Z_{e}}{Z_{a}-Z_{e}}\right)
$$

and being given the evapotranspiration from the saturated soil by:

$$
E_{s}(t)=\operatorname{Min} \mid \begin{aligned}
& C v \cdot E_{0}(t)-E_{u}(t) \\
& r_{s} \cdot C v \cdot E_{0}(t) \cdot\left(1-\frac{Z_{w t}-Z_{e}}{Z_{a}-Z_{e}}\right)
\end{aligned}
$$

The second case occurs if the water table is located below the effective root depth but connected with the root system $\left(Z_{e}>Z_{w t} \geq Z_{r}\right)$. In this case the $E_{u}$ is determined by the static storage of water in the soil, by the plant coverage and by the efficiency of water transpiration defined by the extraction curve. In RibAV, it is assumed that plants transpirate with no restrictions when there are optimum moisture content conditions in the soil $\left(\theta^{*}\right)$. It is considered also that the evapotranspiration is reduced linearly as the moisture is lower (e.g. Laio et al., 2001), until it remains null at the wilting point moisture $\left(\theta_{w p}\right)$. Thereby, if the water content before the evapotranspiration from the unsaturated zone starts is under the wilting point water content $\left(H(t-1) \leq H_{w p}\right), E_{u}$ is null. On the contrary, if $H(t-1)>H_{w p}$, the relative water content $\left(H_{r e l}\right)$ is calculated by the following expression (15) and takes part in the $E_{u}$ equation (16):

$$
\begin{aligned}
& H_{\text {rel }}(t)=\operatorname{Min} \mid \frac{H(t-1)-H_{w p}}{H^{*}-H_{w p}} \\
& E_{u}(t)=\operatorname{Min} \mid \begin{array}{l}
H(t-1)-H_{w p} \\
r u
\end{array} \cdot C v \cdot E_{0}(t) \cdot H_{r e l}(t)
\end{aligned}
$$

Finally, in this case the $E_{s}$ calculation considers a linear increasing evapotranspiration curve (Maddock III and Baird, 2003), the coverage vegetation factor, and the efficiency in water collecting, with a limitation of the available energy after the $E_{u}$ :

$$
E_{s}(t)=\operatorname{Min} \mid \begin{aligned}
& C v \cdot E_{0}(t)-E_{u}(t) \\
& r_{s} \cdot C v \cdot E_{0}(t) \cdot\left(\frac{Z_{w t}(t)-Z_{r}}{Z_{e}-Z_{r}}\right)
\end{aligned}
$$




\section{IMPLEMENTATION OF THE RIBAV MODEL IN MEDITERRANEAN RIPARIAN} ZONES

The evapotranspiration index, $E_{i d x}$

In the present paper, the $E_{i d x}$ is proposed for the modelling of the spatial distribution of different PFTs. The $E_{i d x}$ is a dimensionless measure of the interaction between abiotic and biotic factors in the riparian zone. It is defined as a relation between the actual evapotranspiration rate calculated by RibAV and the potential evapotranspiration corrected by the coverage of the analyzed $\mathrm{PFT}$, for the simulation period between day $t=1$ and day $n$ :

$$
E_{i d x}(t)=\frac{1}{n} \sum_{t=1}^{n} \frac{E(t)}{C v \cdot E_{0}(t)}
$$

where $E$ is the actual evapotranspiration rate, $E_{0}$ is the potential evapotranspiration, and $C v$ is the coverage.

The $E_{i d x}$ assumes values between 0 and 1 . An $E_{i d x}$ value equal to 1 represents a maximum evapotranspiration rate, equivalent to the potential evapotranspiration of the analyzed PFT. On the contrary, a value equal to 0 represents a persistent extinction of the evapotranspiration.

The followed methodology considers as predicted PFT for a specific unit area, the one with a higher value of $E_{i d x}$, compared to the other PFTs analyzed under the same conditions and during the same time-period.

\section{Study sites description}

Two study sites have been selected to implement the RibAV model: the Terde reach in the Mijares River and the Lorcha reach in the Serpis River (Figure 3). Both reaches are located in the Jucar River Basin district, under semi-arid environmental conditions.

The Terde reach (Mijares River). The Terde reach is located in the Mijares River, upstream the village of Sarrión in the province of Teruel (UTM coordinates: 689350,4448916$)$. It is located at 850 m.a.s.l. and it has $539 \mathrm{~m}$ length. Terde is a typical Mediterranean reach that shows an important seasonality and considerably variability in the discharge between humid and dry years. The average annual values of temperature and precipitation are $11^{\circ} \mathrm{C}$ and $500 \mathrm{~mm}$ respectively, being most of the rainfall concentrated in the autumn and spring seasons. The accumulated basin area is $665 \mathrm{~km}^{2}$ and the average daily discharge is $0.855 \mathrm{~m}^{3} \mathrm{~s}^{-1}$ for available data between 1948 and 2009 . Terde can be considered near to natural conditions because there is not important flow regulation upstream and the riparian area is continuous and connected with the terrestrial vegetation areas. Willows and poplars are dominant within the riparian main vegetation. The substrate is varied being predominant gravels or blocks in different areas of the reach.

The Lorcha reach (Serpis River). The Lorcha reach, with $239 \mathrm{~m}$ long, is located in the Serpis River at 229 m.a.s.l. below the Beniarrés dam, near the village of Lorcha in the province of Alicante (UTM coordinates: 733362, 4304165). The average annual values of temperature and precipitation are $18^{\circ} \mathrm{C}$ and $820 \mathrm{~mm}$ 


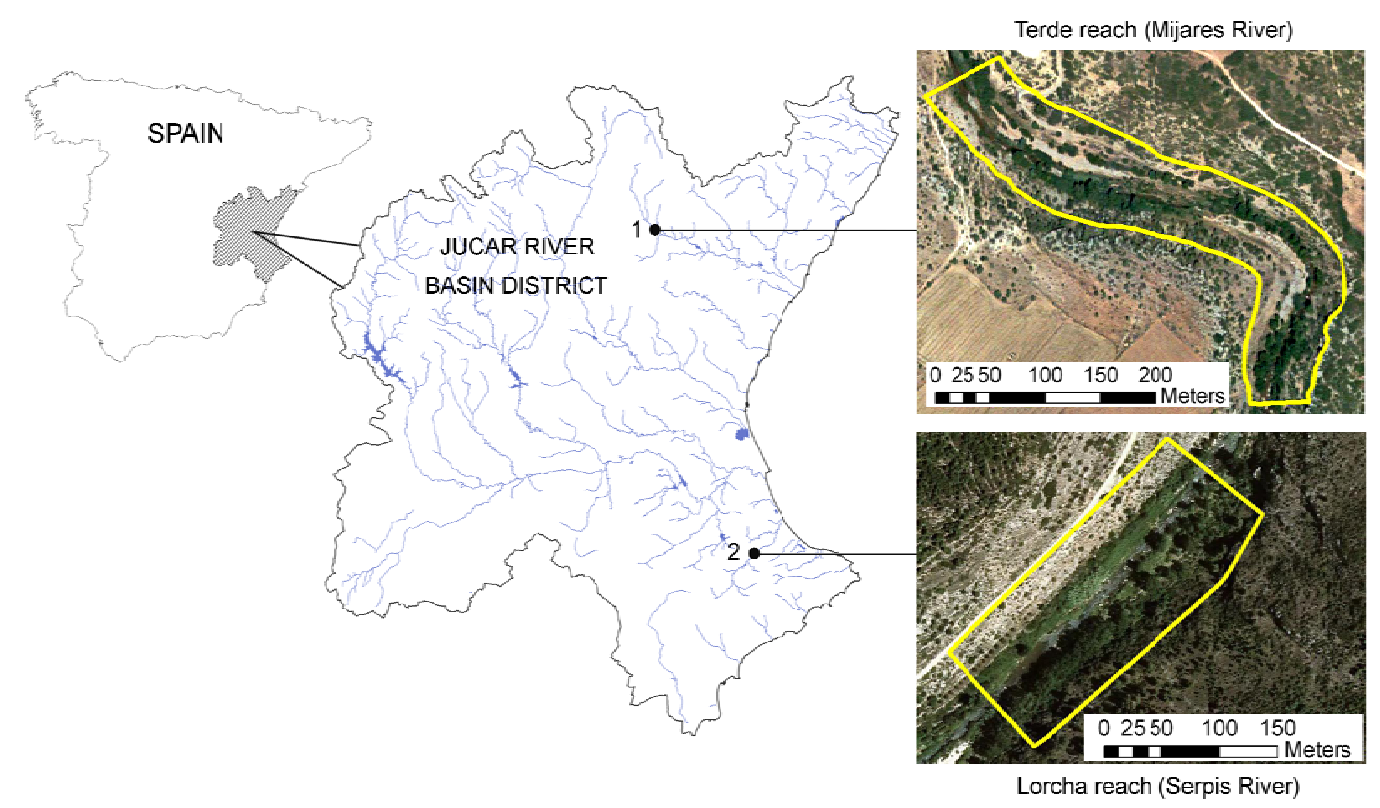

Figure 3. Location of the study sites in the Júcar River Basin District, East Spain. (1) Terde reach in the Mijares River (Teruel, Spain); (2) Lorcha reach in the Serpis River (Alicante, Spain).

respectively, with a summer season especially dry that is characterized by scarcity of rainfall and high temperatures. The accumulated basin area is 753 $\mathrm{km}^{2}$ and the average daily discharge is $1.27 \mathrm{~m}^{3} \mathrm{~s}^{-1}$ for available data between 1998 and 2009. The bed is fairly stable and large blocks are occasionally present. The differences between the both margins are important in terms of substrate and insolation. In the left margin the gravel dominates while in the right margin the substrate is mainly composed by sand. The riparian main vegetation consists of willows, being oleanders and brambles also abundant. The reach has flow regulation upstream. However, the environmental conditions in the riparian zone are considered good in terms of structure, connectivity and diversity.

\section{Plant functional types definition}

Three PFTs were considered for the RibAV model implementation: herbaceous riparian vegetation (HRV), woody riparian vegetation (WRV), and terrestrial vegetation (TV).

The HRV functional type included the non-woody plants that require frequent saturated soil conditions to have a good development. These species have shallow root systems and can be found usually in areas adjacent to the stream, where the water table elevation is also shallow. Different plants, from small herbaceous stands to well-developed reed beds, were included in this PFT. The WRV functional type included riparian woody trees and shrubs, most of them poplars, willows and oleanders. The plants considered in this PFT have long roots with a high efficiency extracting water from the saturated zone. Although they have also a certain tolerance to root asphyxia, it is lower than those included in HRV. Finally, TV grouped all the terrestrial vegetation, meaning all the herbs, shrubs and trees that are not part of the riparian ecosystem itself. In fact, the species included in this PFT represent the zonal vegetation of the area and they would be found instead of the riparian plants if there were no water 
flow and, therefore, the water table was found at a greater depth under the soil surface.

\section{Model inputs definition}

Different institutions services, as the National Climatic Data Bank of the State Agency of Meteorology (AEMET), the Centre for Hydrographical Studies (CEHCEDEX), and the Valencian Institute for Agricultural Research (IVIA), supplied the data needed to obtain the hydro-meteorological inputs for the RibAV model simulations: daily precipitation $(P)$, daily potential evapotranspiration $\left(E_{0}\right)$, and daily river flow $(Q)$.

These supplied data series required an adjustment to each site location. Seven meteorological stations were considered to interpolate the precipitation data for the Terde reach; five in the case of the Lorcha reach. The inverse distance weighting method was applied for this purpose.

Temperature series were employed for the $E_{0}$ data estimation. For the Terde reach the temperature data came from the meteorological station of Sarrión (AEMET), and was corrected for elevation $\left(6.5^{\circ} \mathrm{C} / 1000 \mathrm{~m}\right)$. In the Lorcha reach the temperature series came from different surrounding meteorological stations (AEMET, IVIA) due to their lack of information in different periods along the series. Available data of $E_{0}$ obtained by Penman-Monteith equation (Planes station, IVIA) were taken as reference to calibrate by regression the simplified Hargreaves equation (Allen et al., 1998). Finally the calibration resulted in the reduction of the default correction factor to a value of $0.001887\left(R^{2}=0.883\right)$. The following modified Hargreaves equation was applied in the in-site $E_{0}$ data series estimation:

$$
E_{0}(t)=0.001887 \cdot\left(T_{\text {med }}(t)+17.78\right) \cdot R_{a}(t) \cdot\left(T_{\text {max }}(t)-T_{\text {min }}(t)\right)^{0.5}
$$

where, $\mathrm{T}_{\text {med }}, \mathrm{T}_{\max }$ and $\mathrm{T}_{\min }$ are the medium, maximum and minimum daily temperatures respectively, and $R_{a}$ is the daily extraterrestrial radiation tabulated for each month (Allen et al., 1998).

The daily river flow data series needed no corrections. In the Terde reach these data were available from the gauging station named 'Río Mijares en Terde' (CEDEX) which is located $550 \mathrm{~m}$ downstream of the study site. The watershed area is very similar and there are no tributaries or springs between them. The same occurred in the Lorcha reach. The gauging station named 'Villalonga' (CEDEX) is located $3.12 \mathrm{~km}$ downstream of the reach and there are not important contributions or withdrawals between both points. The periods in which all the hydro-meteorological data were available were from January $1^{\text {st }}$, 1949 to December $31^{\text {st }}$, 2009 in the Terde reach and from January $1^{\text {st }}, 1999$ to December $31^{\text {st }}, 2009$ in the Lorcha reach. Monthly averaged values and coefficient of variation of these hydro-meteorological data are shown in ¡Error! No se encuentra el origen de la referencia. 4.

In addition, soil and vegetation maps were required for the model implementation. All these maps had a pixel size of $1 \mathrm{~m}$. The soil maps, containing the different soil types, allowed the selection of the corresponding set of parameters in each cell during the model simulation (Table 1.). On the other hand, the vegetation maps that contained the observed PFTs in each study site were only 

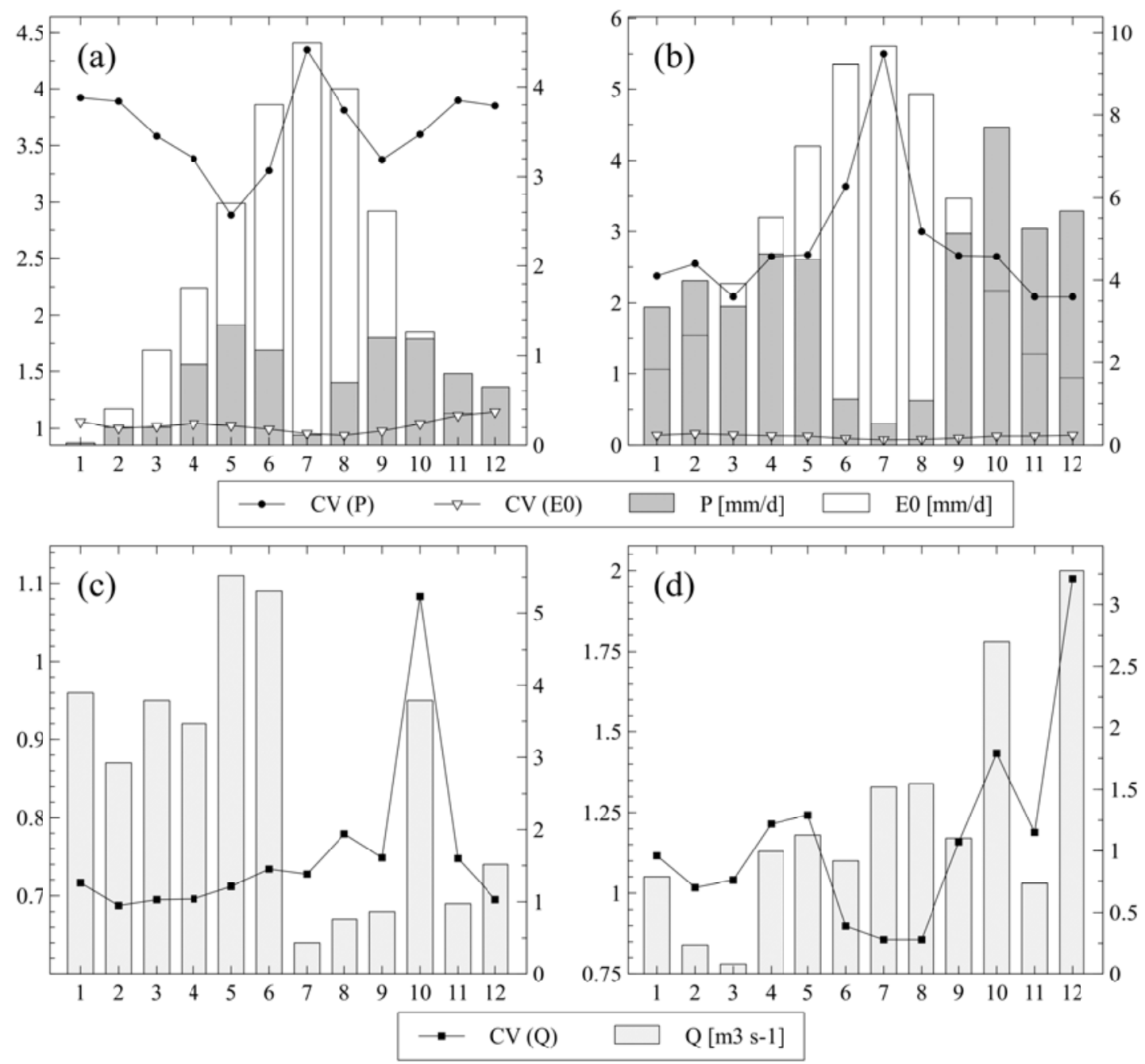

Figure 4. Monthly average data (left axes) and coefficient of variation (right axes) of the daily precipitation $(P)$ and daily potential evapotranspiration $\left(E_{0}\right)$ from the Terde $(a)$ and Lorcha reaches (b); monthly average data (left axes) and coefficient of variation (right axes) of the daily mean river discharge $(Q)$ from the Terde $(c)$ and Lorcha reaches $(d)$.

used for comparison issues during the calibration and the validation processes in the model performance evaluation.

For the soil parameters establishment, ten soil samples (extracted at 30-60 cm soil depth) from each reach were analyzed in one of the soil laboratories of the Universitat Politècnica de València (Spain). The percentages of gravel, sand, silt, clay and organic matter were introduced in the model "Soil Water Characteristics" (Saxton and Rawls, 2006), which provided for each soil type the water retention curves, defined by the following parameters: the soil moisture at field capacity, the porosity, the saturated hydraulic conductivity, the bubble pressure, and the porosity index. The $D_{c}$ values were established considering the texture of the soils (Brouwer et al., 1985), and a $\Psi_{f c}$ of $33 \mathrm{kPa}$ was considered.

The reference maps of water table elevation $\left(Z_{w t, j}\right)$ were obtained using the Guad-2D software, which includes the finite volume based two-dimensional model of the same name for the numerical simulation of transient flows over 
Table 1. Basic parameters of the soil types present in the Terde reach and in the Lorcha reach.

\begin{tabular}{|c|c|c|c|c|c|c|c|}
\hline & ID & $\Phi$ & $\lambda$ & $\Psi_{b}$ & $K_{s}$ & $D_{c}$ & Soil type description \\
\hline \multirow{10}{*}{ 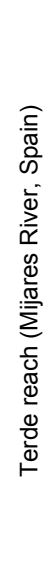 } & 1 & 0.397 & 0.530 & 3.848 & 56.24 & 4.0 & Light coloured soil mainly composed of sand and gravel. Large blocks and bedrock outcrops are present. \\
\hline & 2 & 0.436 & 0.209 & 0.342 & 22.65 & 6.0 & Dark soil with great boulders present on the surface; silt and gravel dominate in depth. \\
\hline & 3 & 0.441 & 0.226 & 2.625 & 19.91 & 7.0 & Similar to soil 2 but with a higher presence of gravel and a lighter colour. \\
\hline & 4 & 0.406 & 0.277 & 1.037 & 42.76 & 8.0 & Fine textured soil with a silt-clay main composition. The absence of gravel is characteristic. \\
\hline & 5 & 0.412 & 0.220 & 0.057 & 28.19 & 4.0 & Soil that consists of coarse sand and gravel. Surface has boulders which presence decrease in depth. \\
\hline & 6 & 0.432 & 0.184 & 0.246 & 37.09 & 4.0 & Soil that mainly consists of coarse sand and gravel. It contains some silt conglomerates. \\
\hline & 7 & 0.414 & 0.251 & 0.024 & 97.96 & 4.0 & Sandy and loose soil without plasticity. \\
\hline & 8 & 0.423 & 0.231 & 0.056 & 34.45 & 5.0 & Black loamy soil with a strong presence of gravel and boulders. \\
\hline & 9 & 0.398 & 0.278 & 2.370 & 26.83 & 6.0 & Light coloured soil composed mainly of sand and silt. \\
\hline & 10 & 0.403 & 0.207 & 0.045 & 25.06 & 5.5 & Soil with medium particle size. Its composition is mainly gravel with a matrix of very coarse sand. \\
\hline \multirow{10}{*}{ 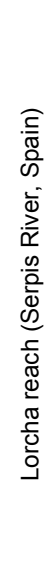 } & 1 & 0.401 & 0.456 & 5.837 & 36.78 & 6.0 & Soil composed of sand and silt. \\
\hline & 2 & 0.412 & 0.315 & 4.403 & 22.62 & 7.0 & Soil composed mostly of silt. \\
\hline & 3 & 0.407 & 0.266 & 2.475 & 32.00 & 6.0 & Sand and silt are the textures that dominate this soil. \\
\hline & 4 & 0.450 & 0.238 & 4.343 & 15.81 & 8.0 & Soil mainly composed of silt and without gravel. \\
\hline & 5 & 0.502 & 0.233 & 1.253 & 46.38 & 5.0 & $\begin{array}{l}\text { A soil with two marked horizons, the upper one with organic matter predominance and the lower one with } \\
\text { gravel. }\end{array}$ \\
\hline & 6 & 0.458 & 0.206 & 1.196 & 14.32 & 4.0 & Soil mainly composed of sand and gravel. \\
\hline & 7 & 0.441 & 0.215 & 0.187 & 30.53 & 4.0 & Soil composed of sand and gravel. \\
\hline & 8 & 0.435 & 0.238 & 0.984 & 40.39 & 6.0 & Composed mainly of sand and silt. \\
\hline & 9 & 0.412 & 0.209 & 0.021 & 38.82 & 4.0 & Soil mainly composed of gravel but also of sand. \\
\hline & 10 & 0.486 & 0.260 & 0.516 & 40.02 & 6.0 & Soil composed of gravel and sand, with an important presence of organic matter. \\
\hline
\end{tabular}

The specific meaning of the symbol representing each parameter can be found in the Appendix section. 
irregular topography, under the shallow water equations hypothesis (Murillo et al., 2008). The digital elevation model and a Manning roughness map (roughness estimated according to Cowan's procedure) were included as input of this model. Sixteen reference flows $\left(Q_{j}\right)$ for the Terde reach ranging from 0 to $150 \mathrm{~m}^{3} \mathrm{~s}^{-1}$ and other thirteen for the Lorcha reach ranging from 0.1 to $75 \mathrm{~m}^{3} \mathrm{~s}^{-1}$ were modeled. Once the water surface elevation maps were obtained, they were interpolated horizontally by the Thiessen proximity algorithm to represent the $Z_{w t}$ under the banks along the reaches. The same pixel size of $1 \mathrm{~m}$ was maintained for all the input maps, also the same surface extension for each specific study site.

\section{Calibration and validation methodology}

The model was calibrated in the Terde reach (Mijares River, Spain) considering a time period of 61 years (1949-2009). The calibration process required iterative variations of the vegetation parameters values followed by the comparison between the simulated map (obtained using the $E_{i d x}$ as conclusive index for the distribution of the PFTs) and the map corresponding to the observed vegetation. This comparison did not consider those cells in which the observed vegetation was almost inexistent, for example, those areas where bare sediment was observed, because they are mainly gravel bars caused by sediment deposition processes that could not be simulated through the model.

The value of $0.97 \mathrm{mmMPa}^{-1} \mathrm{~h}^{-1}$ reported in the literature (Ryel et al., 2002; Zhen and Wang, 2007) for $\mathrm{Cr}$ was selected for all the analyzed PFTs. Regarding the pressures, $\Psi^{*}$ were set as $500 \mathrm{KPa}$ (Eagleson, 2002), while $\boldsymbol{\psi}_{\text {wp }}$ were set as $1500 \mathrm{KPa}$ for riparian PFTs (e.g., Kramer and Boyer, 1995) and $3000 \mathrm{KPa}$ for the adapted to semi-arid conditions terrestrial vegetation (Laio et al., 2001). Finally, several assumptions conditioned the establishment of the parameters related to the vegetal coverage fraction $(\mathrm{Cv})$. The riparian vegetation is typically lush due to the high contribution of resources (water, nutrients, sediments, etc.) by the river. Through aerial photographs and field observations this fact was verified and we decided to consider complete the soil coverage by the riparian vegetation in the vegetated patches. The terrestrial vegetation in Mediterranean semi-arid environments is usually more scattered than most of the riparian vegetation, which was corroborated especially in the reach used for the calibration of the model (Terde). In consequence, values of 1 to HRV and WRV, and 0.8 to TV were assigned.

The remaining vegetation parameters needed to be calibrated. Values from 0.5 to $1.3 \mathrm{~m}$ were attempted for the establishment of $D_{r}$ in HRV. Those values were related to $D_{e}$ values ranging between 0.3 and $0.9 \mathrm{~m}$, avoiding incoherent combinations in which the $D_{e}$ values were higher than $D_{r}$. The $D_{r}$ values for WRV ranged between 3.0 and $6.0 \mathrm{~m}$; these values were related to $D_{e}$ values between 0.5 and $3.0 \mathrm{~m}$. The $r_{u}$ value for HRV was forced to be the lowest, between 0.3 and 0.7 , and $r_{s}$ the highest, between 0.6 and 0.9 . In addition, $D_{\text {sat }}$ was forced to be the highest considering values between 0.5 and $1 \mathrm{~m}$ above the soil surface. The calibration of $r_{u}$ and $r_{s}$ considered a rank of 0.3-0.8 for WRV. TV was supposed to obtain a maximum value of $r_{u}(0.9-1.0)$, an approximately null value of $r_{s}(0.0-0.1)$, and a critical $D_{\text {sat }}$ located under the soil surface, just below the effective root depth. After these parameters were considered to be correctly calibrated, the model was spatially validated in the Lorcha reach (Serpis River, Spain) considering a time period of 11 years (1999-2009). 


\section{Objective functions}

The confusion matrix that resulted from the comparison between the observed and the simulated maps allowed the calculation of the correctly classified instances $(C C l)$, the kappa $(k)$ coefficient of agreement (Cohen, 1960), and the weighted kappa $\left(k^{*}\right)$ coefficient (Cohen, 1968). These coefficients, which maximum value is 1 representing a perfect agreement, were employed in the model performance analyses comparing one to one the distribution of all the PFTs present in the maps.

Additionally, other criteria were analyzed in terms of the presence/absence of each PFT: the area under the curve $(A \cup C)$, the sensitivity as correctly predicted positive fraction, the specificity as correctly predicted negative fraction, the omission rate as falsely predicted negative fraction, the commission rate as falsely predicted positive fraction, and the accuracy $(A C C)$ understood as the proportion of the presence and absence records correctly identified.

\section{RESULTS}

The model was considered calibrated for the prediction of the PFTs distribution in the Terde reach with the vegetation parameters shown in Table 2. Root depths resulted on values under a meter for HRV, and approximately two meters for TV. In both PFTs the distance between $D_{r}$ and $D_{e}$ was very small, only $20-30 \mathrm{~cm}$. WRV obtained higher values for $D_{r}(3.2 \mathrm{~m})$ that contrasted with a reduced value of $D_{e}(0.8 \mathrm{~m})$, very similar to the value established for HRV $(0.6$ $\mathrm{m})$.

Table 2. Vegetation basic parameters for the plant functional types considered in the RibAV model implementation.

\begin{tabular}{lllllllll}
\hline PFTs & $D_{r}$ & $D_{e}$ & $D_{\text {sat }}$ & $r_{u}$ & $r_{s}$ & $\psi^{*}$ & $\psi_{\text {wp }}$ & $C V$ \\
\hline HRV & 0.8 & 0.6 & -0.7 & 0.5 & 0.6 & 500 & 1500 & 1 \\
WRV & 3.2 & 0.8 & -0.3 & 0.7 & 0.3 & 500 & 1500 & 1 \\
TV & 1.9 & 1.6 & 1.59 & 1 & 0 & 500 & 3000 & 0.8 \\
\hline
\end{tabular}

The specific meaning of the symbol representing each parameter can be found in the Appendix section.

HRV, herbaceous riparian vegetation; PFTs, plant functional types; TV, terrestrial vegetation; WRV, woody riparian vegetation.

The phreatophytic character of the riparian plants is expressed through the negative values of $D_{\text {sat. }}$. The more negative the value for asphyxia by saturation root depth is the greater is the flood elevation resistance of the PFT. Taking this into account, HRV was forced to be the more resistant obtaining a $D_{\text {sat }}$ value of 0.7 meters above the soil surface elevation; half a meter less was assigned to WRV (0.3 $\mathrm{m}$ above the soil surface), and just under the $D_{e}$ was assigned to TV because this PFT groups non-phreatophytic species.

The phreatophytic or non-phreatophytic character of the different species included in each PFT was also emphasized through the transpiration factors $\left(r_{u}\right.$ and $r_{s}$ ). The more phreatophytic the PFT is the higher $r_{s}$ value must be assigned. Following the previous consideration, a high $r_{s}$ value of 0.6 was assigned to HRV and lower values were assigned to WRV; TV obtained a null value for this parameter. On the other hand, a maximum $r_{u}$ value of 1 was 
assigned to TV while the riparian PFTs obtained lower values due to the disadvantage on the transpiration from this zone compared to the terrestrials. Indeed, HRV obtained a lower $r_{u}$ value than $r_{s}$

The objective functions results (Table 3 ) represent the quality performance of the calibration and validation from two points of view: considering simultaneously all the PFTs and comparing each PFT presence/absence simulation agreement.

Table 3. Indices of the RibAV model calibration and validation performance using $E_{i d x}$ as conclusive index for PFTs distribution.

\begin{tabular}{|c|c|c|c|c|}
\hline \multicolumn{5}{|c|}{ CALIBRATION CASE STUDY: Terde reach (Mijares River, Spain) } \\
\hline \multirow{3}{*}{$\begin{array}{l}\text { Three PFTs confusion } \\
\text { matrix }\end{array}$} & $\mathrm{CCl}$ & \multicolumn{3}{|c|}{0.675} \\
\hline & $\mathrm{k}$ & \multicolumn{3}{|c|}{0.460} \\
\hline & $k^{*}$ & \multicolumn{3}{|c|}{0.670} \\
\hline \multirow{8}{*}{$\begin{array}{l}\text { PFTs absence/presence } \\
\text { confusion matrices }\end{array}$} & & \multicolumn{3}{|c|}{ Plant Functional Type } \\
\hline & & $H R V$ & WRV & $T V$ \\
\hline & AUC & 0.584 & 0.648 & 0.673 \\
\hline & Sensitivity & 0.525 & 0.492 & 0.846 \\
\hline & Specificity & 0.306 & 0.212 & 0.501 \\
\hline & Omission rate & 0.163 & 0.598 & 0.240 \\
\hline & Commission rate & 0.914 & 0.722 & 0.365 \\
\hline & ACC & 0.331 & 0.319 & 0.676 \\
\hline \multicolumn{5}{|c|}{ VALIDATION CASE STUDY: Lorcha reach (Serpis River, Spain) } \\
\hline \multirow{5}{*}{$\begin{array}{l}\text { Three PFTs confusion } \\
\text { matrix }\end{array}$} & $\mathrm{CCl}$ & \multicolumn{3}{|c|}{0.750} \\
\hline & k & \multicolumn{3}{|c|}{0.510} \\
\hline & $k^{*}$ & \multicolumn{3}{|c|}{0.645} \\
\hline & & \multicolumn{3}{|c|}{ Plant Functional Type } \\
\hline & & $H R V$ & WRV & $T V$ \\
\hline \multirow{6}{*}{$\begin{array}{l}\text { Each PFT } \\
\text { presence/absence } \\
\text { confusion matrix }\end{array}$} & AUC & 0.580 & 0.778 & 0.765 \\
\hline & Sensitivity & 0.906 & 0.423 & 0.983 \\
\hline & Specificity & 0.254 & 0.021 & 0.548 \\
\hline & Omission rate & 0.010 & 0.951 & 0.040 \\
\hline & Commission rate & 0.968 & 0.768 & 0.264 \\
\hline & ACC & 0.271 & 0.186 & 0.792 \\
\hline
\end{tabular}

$\mathrm{CCl}$, kappa $(\mathrm{K})$ and weighted kappa $\left(\mathrm{k}^{*}\right)$ indices resulted from confusion matrices that compare every PFT. The other indices were obtained through the absence/presence matrices of each PFT.

ACC, accuracy; $\mathrm{CCl}$, correctly classified instances; HRV, herbaceous riparian vegetation; PFTs, plant functional types; TV, terrestrial vegetation; WRV, woody riparian vegetation.

Confusion matrices that compared the three analyzed PFTs were characterized by $\mathrm{CCl}, k$ and $k^{*}$ coefficients of agreement. $\mathrm{CCl}$ achieved a value of approximately 0.68 in calibration being higher in the validation case study (0.75). In both cases, the $k^{*}$ values ( 0.67 in calibration and 0.65 in validation) were considerably better than the $k$ values ( 0.46 and 0.51 , respectively) proving that RibAV makes not only very few but also reasonable mistakes between PFTs distributions. In both case studies, when the absence/presence of each PFT was studied, values between 0.58 and 0.78 were obtained in terms of AUC for each PFT absence/presence confusion matrix. Sensitivity values higher than 0.42 and good ACC results up to 0.79 , were obtained in addition. 
The static comparison and hierarchical organization of the $E_{i d x}$ values obtained for each observed PFT (Figure 5), resulted to be a good criterion for the prediction of the riparian zonation in the long term, since the actual observed PFT was considered correctly simulated when a higher value of $E_{\mathrm{idx}}$ for the observed PFT was obtained respect to the other PFTs. Consequently, the $E_{i d x}$ was validated as a good indicator for PFTs response/adaptation to the variable environmental conditions of each unit area.
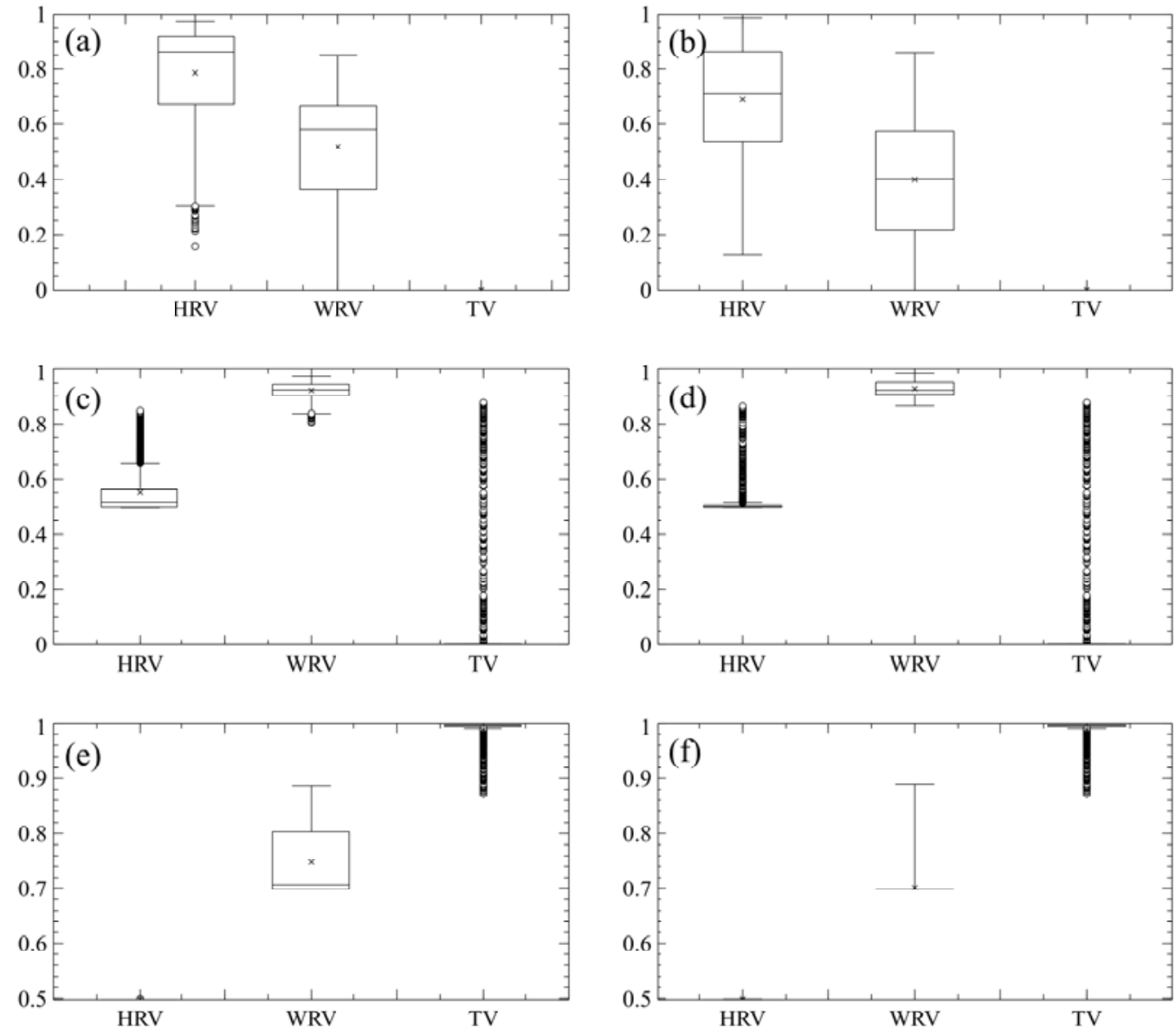

Figure 5. RibAV evapotranspiration index $\left(\mathrm{E}_{\mathrm{idx}}\right)$ values obtained for the different plant functional types (PFTs) analysed in the cases when the actual observed PFT was herbaceous riparian vegetation (HRV) in Terde (a) and in Lorcha (b), woody riparian vegetation (WRV) in Terde (c) and in Lorcha (d) and terrestrial vegetation (TV) in Terde (e) and in Lorcha (f).

Finally, the model reproduced correctly the transverse distribution of the riparian vegetation at reach scale (Figure 6). The distinction between the terrestrial vegetation and the riparian PFTs was remarkable, with no cells simulated as terrestrial vegetation in typical riparian areas (areas adjacent to the water course, islands, etc.). In the same way, the herbaceous riparian vegetation was located in very wet areas and did not appear in typical terrestrial areas (areas located far from the aquatic zone with lower soil moisture content and considerably deep water table). 

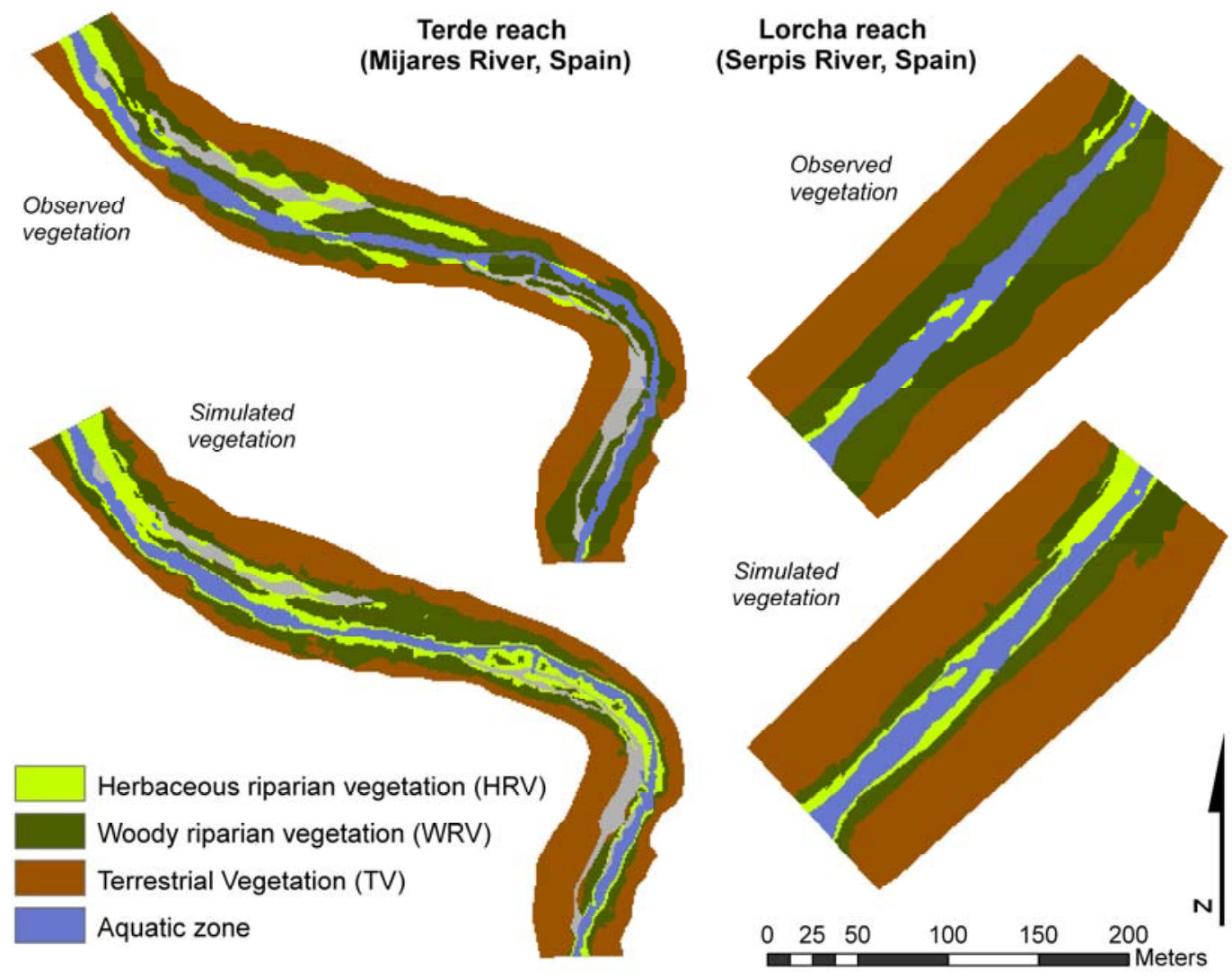

Figure 6. Observed and simulated vegetation maps at both study sites where the RibAV model was calibrated and validated. The plant functional types appear with different colours, whereas bared areas appear in grey.

\section{DISCUSSION AND CONCLUSIONS}

An ecohydrological model for evapotranspiration and vegetation distribution modelling in riparian zones, the RibAV model, is presented. By including the knowledge of many disciplines, this model considers the plant growth from two perspectives of water availability: the static storage and the saturated zone. The RibAV model incorporates the strengths of quantifying and analyzing the evapotranspiration of the riparian vegetation from the perspective of the groundwater (Stromberg et al., 1996; Horton and Clark, 2001; Mac Nish et al., 2000; Horton et al., 2001; Maddock III and Baird, 2003; Baird and Maddock III, 2005; Lamontagne et al., 2005; Lautz, 2008; Schilling and Kiniry, 2007) and the water availability in the unsaturated zone both when there are shallow water tables and when they are far from the surface (Lowrance et al., 1998; Inamdar et al., 1999; Goodrich et al., 2000; Lowrance et al., 2000; Scott et al., 2000; Altier et al., 2002; Dahm et al., 2002). The modelling of water fluxes from the saturated zone, as the hydraulic lift from the saturated zone, means an important milestone developed in RibAV. Through this paper, the mathematical conceptualization of this static tank flow model is described.

The RibAV model is also an innovative tool for water management since the generated rates of evapotranspiration of the different PFTs can determine by themselves how the riparian zone is affecting the water balance. In addition, it 
can be useful in the riverine ecosystems management since it predicts in an efficient manner the different PFTs present in these ecosystems of semi-arid Mediterranean environments. The RibAV model, through its $E_{i d x}$ calculation, allows not only the presence/absence determination of each riparian PFT but also the goodness of their situation, representing a major improvement respect to other models. Thereby, RibAV provides the scientific community with a tool that frequently has been pointed out as necessary (e.g., Schaeffer and Williams, 1998; Mac Nish et al., 2000; Scott et al., 2000; Snyder and Williams, 2000; Tabacchi et al. 2000; Hughes et al., 2003; Lamontagne, 2005; Lautz, 2008). To accomplish the necessities stated by the European Water Framework Directive (WFD 2000/60/EC), the model required in addition to be spatially distributed, objective that has been accomplished in this paper. In addition, although regarding the habitat characterization protocols available in Europe, many of them include the riparian vegetation structure (Fernandez et al., 2011) no other indexes in use integrate the complex interactions occurring among the soil, water and vegetation, like the $E_{i d x}$ does.

To implement plant distribution models correctly, it is necessary to count on reliable procedures for their calibration and performance evaluation based on efficiency indexes (Manel et al., 2001; Mouton et al., 2010). For the performance analysis of the RibAV model as a PFTs spatial distribution simulation tool, the riparian zones of two semi-arid Mediterranean reaches from different rivers were selected. The model was calibrated in a natural reach called the Terde reach (Mijares River), and then spatially validated in a second study site with flow regulation, the Lorcha reach (Serpis River). A confusion matrix was obtained as a result of the comparison of the observed and the simulated PFTs distribution maps. Then, different criteria based on the confusion matrix were selected to evaluate the model performance and its efficiency in the simulation of the PFTs distribution. The model performed in a good manner under the different discharge regimes of the two case studies. The use of time series with different lengths between study sites demonstrated that is not necessary to analyze extremely long periods in order to obtain good results. In addition, the selected pixel size of $1 \mathrm{~m}$ was a good choice and it is recommended for further applications of the model.

The model set-up involved an important effort in the estimation of the basic parameters. These estimations were based on expert knowledge, field data and calibration techniques. Each group of parameters could be established by one or more of those techniques, increasing the versatility of the model implementation. Other parameters could be established with complementary models (i.e. Saxton and Rawls, 2006). For some vegetation parameters, it was considered recommendable to take into account specific ranks based in the scarce but valuable literature available (i.e., Schenk and Jackson, 2002; González et al., 2012) and the eco-physiological characteristics of each PFT, to delimit the options in the calibration.

RibAV was considered to be correctly implemented once the parameters were calibrated and validated. Several indices were selected in order to combine their potential benefits in the performance evaluation. Although some opinions are against the use of kappa coefficient, it has been considered as a useful tool, better than overall accuracy. Kappa is a simple and standardized tool, effective to establish the agreement between nominal data comparison, and it considers and corrects the agreement achieved by chance (Hagen, 2002; Hanberry et al., 
2012, Manel et al., 2001). Apart from CCl and kappa, AUC was calculated because it is considered to be independent of prevalence despite its high correlation with kappa (Manel et al., 2001). These indices are widely used and are considered as adequate criteria for the categorical evaluation of a model performance (Mouton et al., 2010). The calculation of other absence/presence indices was additionally helpful in the decision making during the calibration process.

The calibration and validation results showed in this paper demonstrate that the model is able to simulate different PFTs distribution satisfactorily through the $E_{i d x}$ comparison in the riparian zone of Mediterranean river reaches. $\mathrm{CCl}$ values of approximately 0.7 , kappa values close to 0.4 and weighted kappa values of 0.6 proved the quality of the RibAV model for predicting PFTs distribution. The capabilities of the model in terms of each PFT absence/presence were also tested, obtaining average AUC values of 0.7 , and ACC values close to 0.4 in riparian PFTs and almost 0.9 in the terrestrial vegetation. The obtained results, $E_{i d x}$ values for each PFT and the simulated maps (Figures 5 and 6), revealed the model capabilities to reproduce correctly the typical transverse distribution of the riparian vegetation in both study sites. This transverse distribution of the vegetation in the riverine areas has been related to the hydrological periods, the topography, the sediment types and the competition between species (Hupp and Osterkamp, 1985, 1996; Naiman et al., 2005).

In summary, the hydrological regime of the rivers in semi-arid environments determine the riparian vegetation distribution and represent the main source of water during the dry season, controlling the local water table elevation. In Mediterranean climates, typically semi-arid, the presence/absence of different PFTs is controlled by their response and adaptation capacity under stress conditions, such as water scarcity periods during the dry season alternated with periods in which the soil is saturated causing root asphyxia. In this sense, it has been demonstrated that the RibAV model, with its base in a soil-plantatmosphere continuum schema, and its $E_{i d x}$, can be applied as an indicator of the vegetation response to fluctuations on saturated and unsaturated water availability. Through this technique, the limitations of analysing the evapotranspiration from the saturated zone and the static storage separately are suppressed, implying that RibAV provides an innovative tool pointed out as necessary. Considering that the natural variability of water sources is not only temporal but also spatial, it is not surprising the frequent adaptation of the riparian vegetation to each river dynamics and variable conditions. The potential use of the described methodology, not only allows the simulation of the vegetation distribution, but also the analysis of the plant well-being in the riparian zones and the exploitation of the different water sources in a combined manner. Since in Mediterranean semi-arid environments the water is a scarce resource, human impacts over the river systems have been traditionally important (e.g., Salinas et al., 2000; Aguiar and Ferreira, 2005). Currently, new threats related to global change impacts make indispensable to have available tools for a responsible management of the environment. RibAV is in addition a useful tool for restoration initiatives and global change scenarios analyses such as climate change scenarios, discharge regulation alternatives, or changes in the land use, since the analyses of different hydrological and meteorological scenarios can be accomplished easily, once the RibAV model is implemented in a study site. 


\section{ACKNOWLEDGEMENTS}

The authors would like to thank the Spanish Ministry of Environment and the Spanish Ministry of Economy and Competitiveness for their financial support through the research projects RIBERA (21.812-061/8511) and SCARCE (Consolider-Ingenio 2010 CSD2009-00065) respectively.

In addition, the authors would like to thank the Hydrological Studies Centre (CEH-CEDEX), the Jucar River Basin Authority $(\mathrm{CHJ})$ and the Spanish National Meteorological Agency (AEMET) for supplying the hydrological data, the aerial photographs and the meteorological data respectively, for the two study sites.

\section{APENDIX. LIST OF SYMBOLS}

\begin{tabular}{|c|c|c|c|}
\hline Symbol & Description & Usual units & Type $\left(^{*}\right)$ \\
\hline $\mathrm{Cv}$ & Plant coverage factor & dimensionless & $\mathrm{BP}$ \\
\hline $\mathrm{Cr}$ & Maximum water conductivity in root-soil interface & $\mathrm{mmMPa}^{-1} \mathrm{~h}^{-1}$ & $\mathrm{BP}$ \\
\hline$C w f(t)$ & Upward capillary water flow & $\mathrm{mmd}^{-1}$ & SV \\
\hline$D_{c}$ & $\begin{array}{l}\text { Maximum depth to consider capillary rise flow from the water } \\
\text { table to the static storage }\end{array}$ & $\mathrm{m}$ & $\mathrm{BP}$ \\
\hline$D_{e}$ & Effective root depth & $\mathrm{m}$ & $\mathrm{BP}$ \\
\hline$D_{r}$ & Maximum root depth & $\mathrm{m}$ & $\mathrm{BP}$ \\
\hline$D_{a}$ & Asphyxia root depth & m & $\mathrm{BP}$ \\
\hline$E_{0}(t)$ & Potential evapotranspiration & $\mathrm{mmd}^{-1}$ & IV \\
\hline$E(t)$ & Actual evapotranspiration & $\mathrm{mmd}^{-1}$ & SV \\
\hline$E_{s}(t)$ & Actual evapotranspiration from the saturated zone of the soil & $\mathrm{mmd}^{-1}$ & SV \\
\hline$E_{u}(t)$ & Actual evapotranspiration from the static storage of the soil & $\mathrm{mmd}^{-1}$ & SV \\
\hline$E_{i d x}$ & RibAV evapotranspiration index & dimensionless & SV \\
\hline$H_{f c}$ & Water content equivalent to field capacity & $\mathrm{mm}$ & DP \\
\hline$H^{*}$ & $\begin{array}{l}\text { Water content equivalent to the optimum plant transpiration } \\
\text { point }\end{array}$ & $\mathrm{mm}$ & DP \\
\hline$H_{\text {rel }}(t)$ & Relative water content & $\mathrm{mm}$ & SV \\
\hline$H(t)$ & Water content in the static storage (ending day $t$ ) & $\mathrm{mm}$ & SV \\
\hline$H_{w p}$ & Water content equivalent to the permanent wilting point & $\mathrm{mm}$ & $\mathrm{DP}$ \\
\hline$I(t)$ & Water inputs to the static storage & $\mathrm{mmd}^{-1}$ & SV \\
\hline$K_{u}(t)$ & Hydraulic conductivity of the unsaturated soil & $\mathrm{mmh}^{-1}$ & SV \\
\hline$K_{s}$ & Hydraulic conductivity of the saturated soil & $\mathrm{mmh}^{-1}$ & $\mathrm{BP}$ \\
\hline$\theta_{f c}$ & Moisture content at field capacity & dimensionless & DP \\
\hline$\theta^{*}$ & Optimum plant transpiration point moisture & dimensionless & $\mathrm{DP}$ \\
\hline$\theta_{w p}$ & Wilting point moisture & dimensionless & $\mathrm{DP}$ \\
\hline$\lambda$ & Pore size distribution index & dimensionless & $\mathrm{BP}$ \\
\hline$P(t)$ & Precipitation & $\mathrm{mmd}^{-1}$ & IV \\
\hline$P e(t)$ & Percolation & $\mathrm{mmd}^{-1}$ & SV \\
\hline$\psi_{50}$ & $\begin{array}{l}\text { Midpoint saturation pressure (corresponding to relative soil } \\
\text { moisture of } 50 \% \text { ) }\end{array}$ & $\mathrm{kPa}$ & DP \\
\hline$\Psi_{b}$ & Bubbling pressure & $\mathrm{kPa}$ & $\mathrm{BP}$ \\
\hline$\psi_{f c}$ & Field capacity point pressure & $\mathrm{kPa}$ & $\mathrm{BP}$ \\
\hline$\Psi(t)$ & Capillary pressure of the soil & $\mathrm{kPa}$ & SV \\
\hline$\psi^{*}$ & Optimum plant transpiration pressure & $\mathrm{kPa}$ & $\mathrm{BP}$ \\
\hline$\psi_{w p}$ & Permanent wilting point pressure & $\mathrm{kPa}$ & BP \\
\hline$\Phi$ & Soil porosity & dimensionless & BP \\
\hline$Q_{j}$ & Immediately higher reference flow & $\mathrm{m}^{3} \mathrm{~s}^{-1}$ & AV \\
\hline$Q_{j-1}$ & Immediately lower reference flow & $\mathrm{m}^{3} \mathrm{~s}^{-1}$ & AV \\
\hline$Q(t)$ & River flow & $\mathrm{m}^{3} \mathrm{~s}^{-1}$ & IV \\
\hline$r_{u}$ & Transpiration factor from the unsaturated zone & dimensionless & $\mathrm{BP}$ \\
\hline$r_{s}$ & Transpiration factor from the saturated zone & dimensionless & $\mathrm{BP}$ \\
\hline $\operatorname{Sr}(t)$ & Surface runoff & $\mathrm{m}^{3} \mathrm{~s}^{-1}$ & SV \\
\hline$U(t)$ & Hydraulic lift or root water uptake & $\mathrm{mmd}^{-1}$ & SV \\
\hline$X(t)$ & Excess water & $\mathrm{mmd}^{-1}$ & SV \\
\hline$Z_{a}^{\prime}$ & Asphyxia by saturation root depth elevation & $\mathrm{m}$ & DP \\
\hline$Z_{c}$ & Minimum elevation to consider capillary rise flow from the & $\mathrm{m}$ & $\mathrm{DP}$ \\
\hline
\end{tabular}


water table to the static storage

$Z_{e} \quad$ Effective root depth elevation

$Z_{r} \quad$ Maximum root depth elevation

$Z_{s} \quad$ Soil surface elevation

$Z_{w t, j} \quad$ Water table elevation maps associated to the $Q_{j}$

$Z_{w, j-1} \quad$ Water table elevation maps associated to the $Q_{j-1}$

$Z_{w t}(t) \quad$ Water table elevation calculated by the model

$\begin{array}{ll}m & \text { DP } \\ m & \text { DP } \\ m & \text { DP } \\ m & \text { AV } \\ m & \text { AV } \\ m & \text { SV }\end{array}$

BP: Basic parameter, DP: Derived parameter, IV: Input variable, SV: State variable, AV: Auxiliary variable

\section{REFERENCES}

Aguiar F, Ferreira MT. 2005. Human-disturbed landscapes: effects on composition and integrity of riparian woody vegetation in the Tagus River basin, Portugal. Environmental Conservation 32(1): 30-41. DOI: 10.1017/S0376892905001992.

Allen RG, Pereira LS, Raes D, Smith M. 1998. Crop evapotranspiration - Guidelines for computing crop water requirements. FAO Irrigation and Drainage Paper $n^{\circ}$. 56. FAO, Rome, Italy. 326 p. ISSN: 0254-5284.

Altier LS, Lowrance R, Williams RG, Inamdar SP, Bosch DD, Sheridan JM, Hubbard RK, Thomas DL. 2002. Riparian ecosystem management model: Simulator for ecological processes in riparian zones. United States Department of Agriculture (USDA). Agricultural Research Service. Conservation Research Report 46, p. 216.

Amenu GG, Kumar P. 2008. A model for hydraulic redistribution incorporating coupled soil-root moisture transport. Hydrology and Earth System Sciences Discussions 12(1): 55-74.

Azami K, Suzuki H, Toki S. 2004. Changes in riparian vegetation communities below a large dam in a monsoonal region: Futase dam, Japan. River Research and Applications 20: 549-563. DOI: 10.1002/rra.763.

Baird KJ, Maddock III T. 2005. Simulating riparian evapotranspiration: a new methodology and application for groundwater models. Journal of Hydrology 312: 176-190. DOI: 10.1016/j.jhydrol.2005.02.014.

Bendix J. 1994. Scale, direction, and pattern in riparian vegetation-environment relationships. Annals of the Association of American Geographers 84(4): 652-665. DOI: 10.1111/j.1467-8306.1994.tb01881.x.

Benjankar R, Egger G, Jorde K, Goodwin P, Glenn NF. 2011. Dynamic floodplain vegetation model development for the Kootenai River, USA. Journal of Environmental Management 92: 3058-3070. DOI: 10.1016/j.jenvman.2011.07.017

Bonham CD. 1989. Measurements for terrestrial vegetation. John Wiley \& Sons, U.S.A. 338 p.

Brinson MM, Verhoeven J. 1999. Riparian forests. In: Hunter, M.L. 1999. Maintaining biodiversity in forest ecosystems. NY, USA, Cambridge University Press. P. 265-299.

Brookes CJ, Hooke JM, Mant J. 2000. Modelling vegetation interactions with channel flow in river valleys of the Mediterranean region. Catena 40: 93-118. DOI: 10.1016/S0341-8162(99)00065-X.

Brouwer C, Goffeau A, Heibloem M. 1985. Irrigation Water Management: Training Manual No. 1 - Introduction to Irrigation. FAO Irrigation water management, Training manuals. ISSN: $1020-4261$. http://www.fao.org/docrep/R4082E/R4082E00.htm.

Butler Jr. JJ, Kluitenberg GJ, Whittemore DO, Loheide II SP, Jin W, Billinger MA, Zhan X. 2007. A field investigation of phreatophyte-induced fluctuations in the water table. Water Resources Research 43: W02404. DOI: 10.1029/2005WR004627.

Campbell GS. 1974. A simple method for determining unsaturated conductivity from moisture retention data. Soil Science 117(6): 311-314. DOI: 10.1097/00010694-197406000-00001.

Canadell J, Jackson RB, Ehleringer JR, Mooney HA, Sala OE, Schulze ED. 1996. Maximum rooting depth of vegetation types at the global scale. Oecologia 108: 583-595.

Causton DR. 1988. Introduction to vegetation analysis: principles, practice and interpretation. Unwin Hyman Ltd., London. 342 p.

Choi SU, Yoon B, Woo H. 2005. Effects of dam-induced flow regime change on downstream river morphology and vegetation cover in the Hwang river, Korea. River Research and Applications 21: 315-325. DOI: 10.1002/rra.849.

Cohen J. 1960. A coefficient of agreement for nominal scales. Educational and psychological measurement 20(1): 3746. DOI: $10.1177 / 001316446002000104$

Cohen J. 1968. Weighted kappa: Nominal scale agreement provision for scaled disagreement or partial credit. Psychological Bulletin 70 (4): 213-220. DOI: 10.1037/h0026256.

Cooper A, Shine T, McCann T, Tidane DA. 2006. An ecological basis for sustainable land use of Eastern Mauritanian wetlands. Journal of Arid Environments 67 (1): 116-141. DOI: 10.1016/j.jaridenv.2006.02.003.

Dahm CN, Cleverly JR, Allred J, Thibault JR, Mcdonnell D, Gilroy D. 2002. Evapotranspiration at the land/water interface in a semi-arid drainage basin. Freshwater Biology 47: 831-843. DOI: 10.1046/j.1365-2427.2002.00917.x.

David TS, Henriques MO, Kurz-Besson C, Nunes J, Valente F, Vaz M, Pereira JS, Siegwolf R, Chaves M, Gazarini LC, David JS. 2007. Water-use strategies in two co-occurring Mediterranean evergreen oaks: surviving the summer drought. Tree Physiology 27 (6): 793-803. DOI: 10.1093/treephys/27.6.793

Dingman SL. 2002. Physical hydrology. New Jersey, U.S.A. Prentice Hall. 646 p.

Eagleson PS. 2002. Ecohydrology: Darwinian expression of vegetation form and function. Cambridge University Press, United Kingdom. 443 p.

Fernández D, Barquín J, Raven PJ. 2011. A review of river habitat characterisation methods: methods: indices vs. characterisation protocols. Limnetica 30(2): 217-234

García-Arias A, Francés F, Ferreira T, Egger G, Martínez-Capel F, Garófano-Gómez V, Andrés-Doménech I, Politti E, Rivaes R, Rodríguez-González P. Implementing a dynamic riparian vegetation model in three European river systems. Ecohydrology, Accepted with minor revisions.

Glenz C. 2005. Process-based, Spatially-explicit Modelling of Riparian Forest Dynamics in Central Europe - Tool for Decision making in River Restoration. PhD. Thesis, Dir.: Rodolphe Schlaepfer. University of Lausanne, Lausanne, Switzerland, p. 220. DOI : 10.5075/epfl-thesis-3223 
González E, González-Sanchis M, Comín FA, Muller E. 2012. Hydrologic thresholds for riparian forest conservation in a regulated large Mediterranean river. River Research and Applications 28:71-80. DOI: 10.1002/rra.1436

Goodrich DC, Scott R, Qi J, Goff B, Unkrich CL, Moran MS, Williams D, Schaeffer S, Snyder K, MacNish R, Maddock T, Pool D, Chehbouni A, Cooper D, Eichinger W, Shuttleworth W, Kerr Y, Marsett W, Ni W. 2000. Seasonal estimates of riparian evapotranspiration using remote and in-situ measurements. Journal of Agricultural and Forest Meteorology 105: 281-309.

Guymon GL. 1994. Unsaturated zone hydrology. Prentice Hall, U.S.A. 210 p.

Hagen A. 2002. Technical report: comparison of maps containing nominal data. RIVM project: MAP-SOR S/550002/01/RO, order no. 143699. Maastricht (The Netherlands): Research Institute for Knowledge Systems.

Hanberry BB, He HS, Dey DC. 2012. Sample sizes and model comparison metrics for species distribution models. Ecological Modelling 227: 29-33. DOI: 10.1016/j.ecolmodel.2011.12.001

Horton JL, Clark JL. 2001. Water table decline alters growth and survival of Salix gooddingii and Tamarix chinensis seedlings. Forest Ecology and Management 140: 239-247. DOI: 10.1016/S0378-1127(00)00314-5.

Horton JL, Kolb TE, Hart SC. 2001. Responses of riparian trees to interannual variation in ground water depth in a semi arid river basin. Plant Cell and Environment 24: 293-304.

Hughes F, Barsoum N, Belleudy P, Lambs L, Marigo G, Muller E, Nilsson C, Rood S. 2003. What are the key hydrological processes? In: Hughes F. (Ed.) 2003. The Flooded Forest: guidance for policy makers and river managers in Europe on the restoration of floodplain forests. FLOBAR 2 Project / UE, Department of Geography, University of Cambridge.

Hupp CR, Osterkamp WR. 1985. Bottomland vegetation distribution along Passage Creek, Virginia, in relation to fluvial landforms. Ecology 66: 670-681.

Hupp CR, Osterkamp WR. 1996. Riparian vegetation and fluvial geomorphic processes. Geomorphology 14: 277-295.

Inamdar SP, Sheridan JM, Williams RG, Bosch DD, Lowrance RR, Altier LS, Thomas DL. 1999. Riparian ecosystem management model (REMM): I. Testing of the hydrologic component for a coastal plain riparian system. American Society of Agricultural Engineers 42 (6): 1679-1689.

Kellman, M.; Roulet, N. 1990. Nutrient Flux and Retention in a Tropical Sand-Dune Succession. Journal of Ecology 78 (3): 664-676

Kramer PJ, Boyer JS. 1995. Water relations of plants and soils. Academic Press Ltd, U.S.A. 495p.

Laio F, Porporato A, Ridolfi L, Rodríguez-Iturbe I. 2001. Plants in water-controlled ecosystems: active role in hydrologic processes and response to water stress; II Probabilistic soil moisture dynamics. Advances in Water Resources 24: 707-723. DOI: 10.1016/S0309-1708(01)00007-0

Lambers H, Chapin III FS, Pons TL. 1998. Plant physiological ecology. U.S.A. Springer. 540 p.

Lambs L. 2004. Interactions between groundwater and surface water at river banks and the confluence of rivers. Journal of Hydrology 288: 312-326. DOI: 10.1016/j.jhydrol.2003.10.013.

Lamontagne S, Cook PC, O'Grady A, Eamus D. 2005. Groundwater use by vegetation in a tropical savanna riparian zone (Daly River, Australia). Journal of Hydrology 310: 280-293. DOI: 10.1016/j.jhydrol.2005.01.009.

Larcher W. 2003. Physiological plant ecology: ecophysiology and stress physiology of functional groups. U.S.A. Springer, 3rd. edition. $506 \mathrm{p}$.

Lautz LK. 2008. Estimating groundwater evapotranspiration rates using diurnal water-table fluctuations in a semi-arid riparian zone. Hydrogeology Journal 16 (3): 483-497. DOI: 10.1007/s10040-007-0239-0.

Lee JE, Oliveira RS, Dawson TE, Fung I. 2005. Root functioning modifies seasonal climate. Proceedings of the National Academy of Sciences U.S.A (PNAS) 102: 17576-17581. DOI: 10.1073/pnas.0508785102.

Lite SJ, Bagstad KJ, Stromberg JC. 2005. Riparian plant species richness along lateral and longitudinal gradients of water stress and flood. Journal of Arid Environments 63: 785-813. DOI: 10.1016/j.jaridenv.2005.03.026.

Lite SJ, Stromberg JC. 2005. Surface water and ground-water thresholds for maintaining Populus-Salix forests, San Pedro River, Arizona. Biological Conservation 125: 153-167. DOI: 10.1016/j.biocon.2005.01.020.

Lowrance R, Altier L, Williams R, Inambar S, Bosch D, Sheridan J, Thomas D, Hubbard R. 1998. The riparian ecosystem management model: simulator for ecological processes in buffer systems. In: Proceedings of the First Federal Interagency Hydrologic Modelling Conference, Las Vegas NV. 1: 81-88.

Lowrance R, Altier LS, Williams RG, Inamdar SP, Sheridan JM, Bosch DD, Hubbard RK, Thomas DL. 2000. REMM: the riparian ecosystem management model. Journal of Soil and Water Conservation 55 (1): 27-34.

Mac Nish RD, Unkrich CL, Smythe E, Goodrich DC, Maddock III T. 2000. Comparison of riparian evapotranspiration estimates based on a water balance approach and sap flow measurements. Agricultural and Forest Meteorology 105: 271-279. DOI: 10.1016/S0168-1923(00)00196-9.

Maddock III T, Baird KJ. 2003. A riparian evapotranspiration package for Modflow-96 and Modflow-2000. Department of Hydrology and Water Resources, University of Arizona. $60 \mathrm{p}$.

Malanson GP. 1993. Riparian Landscapes. Cambridge University Press, 269 p.

Manel S, Williams HC, Ormerod SJ. 2001. Evaluating presence-absence models in ecology: the need to account for prevalence. Journal of Applied Ecology 38(5): 921-931. DOI: 10.1046/j.1365-2664.2001.00647.x.

Merritt, D.M.; Scott, M.L.; Poff, N.L.; Auble, G.T.; Lytle, D.A. 2010. Theory, methods and tools for determining environmental flows for riparian vegetation: riparian vegetation-flow response guilds. Freshwater Biology 55 (1): 206-225. DOI: 10.1111/j.1365-2427.2009.02206.x.

Mouton AM, De Baets B, Goethals PLM. 2010. Ecological relevance of performance criteria for species distribution models. Ecological Modelling 221(26): 1995-2002. DOI: 10.1016/j.ecolmodel.2010.04.017.

Murillo J, Rodríguez Pallarés M, Andrés-Urrutia A, Brufau P, García-Navarro P. 2008. A mathematical model for numerical simulation of shallow water flow: Description and practical application of GUAD 2D. Proceedings of the iEMSs Fourth Biennial Meeting: International Congress on Environmental Modelling and Software (iEMSs 2008). International Environmental Modelling and Software Society, Barcelona, Spain. (3) 1431-1438. ISBN: 978-84-7653074-0.

Naiman RJ, Décamps H, McClain ME. 2005. Riparia: ecology, conservation, and management of streamside communities. Elsevier Academic Press. 430 p.

Ocampo CJ, Sivapalan M, Oldham C. 2006. Hydrological connectivity of upland-riparian zones in agricultural catchments: Implications for runoff generation and nitrate transport. Journal of Hydrology 331: 643-658. DOI: 10.1016/j.jhydrol.2006.06.010. 
Perona P, Molnar P, Savina M, Burlando P. 2009. An observation-based stochastic model for sediment and vegetation dynamics in the floodplain of an Alpine braided river. Water Resources Research 45 (9): W09418. DOI: 10.1029/2008WR007550

Porporato, A.; Laio, F.; Ridolfi, L.; Rodríguez-Iturbe, I. 2001. Plants in water controlled ecosystems: active role in hydrologic processes and response to water stress, III. Vegetation water stress. Advances in Water Resources 24: 725-744. DOI: 10.1016/S0309-1708(01)00006-9.

Quevedo D, Francés F. 2008. A conceptual dynamic vegetation-soil model for arid and semi-arid zones. Hydrology and Earth Systems Sciences 12: 1175-1187. DOI: 10.5194/hess-12-1175-2008.

Rawls W J, Ahuja LR, Brakensiek D, Shirmohammadi A. 1993. Infiltration and soil wáter movement. p. 5.1-5.51. In: D. Maidment (ed.) Handbook of hydrology. McGraw-Hill, New York.

Richards KS, Hughes FMR, El-Hames AS, Harris T, Pautou G, Peiry JL, Girel J. 1996. Integrated field, laboratory and numerical investigations of hydrological influences on the establishment of riparian tree species. P. 611-635. In: Anderson, M.; Walling, D.; Bates, P. 1996 (Ed). Floodplain processes. John Wiley \& Sons Ltd.

Richards K, Brasington J, Hughes F. 2002. Geomorphic dynamics of floodplains: ecological implications and potential modelling strategy. Freshwater Biology 47: 559-579. DOI: 10.1046/j.1365-2427.2002.00920.x.

Rodríguez-Iturbe I, Porporato A. 2004. Ecohydrology of water-controlled ecosystems: soil moisture and plant dynamics. Cambridge University Press. 442 p.

Rodríguez-Iturbe I, Porporato A, Laio F, Ridolfi L. 2001. Plants in water controlled ecosystems: active role in hydrologic processes and response to water stress, I. Scope and general outline. Advances in Water Resources 24: 695-705. DOI: 10.1016/S0309-1708(01)00004-5.

Ryel RJ, Caldwell M, Yoder CK, Or D, Leffler AJ. 2002. Hydraulic redistribution in a stand of Artemisia tridentata: evaluation of benefits to transpiration assessed with a simulation model. Oecologia 130: 173-184. DOI 10.1007/S004420100794.

Salinas MJ, Blanca G, Romero AT. 2000. Evaluating riparian vegetation in semi-arid Mediterranean watercourses in the south-eastern Iberian Peninsula. Environmental Conservation 27(1): 24-35.

Saxton KE, Rawls WJ, Romberger JS, Papendick RI. 1986. Estimating generalized soil water characteristics from texture. Transactions of the American Society of Agricultural Engineers 50 (4): 1031-1035.

Saxton KE, Rawls WJ. 2006. Soil Water Characteristic Estimates by Texture and Organic Matter for Hydrologic Solutions. Soil Science Society of America 70 (5): 1569-1578. DOI: 10.2136/sssaj2005.0117.

Schaeffer SM, Williams DG. 1998. Transpiration of desert riparian forest canopies estimated from sap flux. American Meteorological Society, Special Symposium on Hydrology, Phoenix, Arizona, 11-16 Jan 1998. Session 1, paperP2.10.

Schenk HJ, Jackson RB. 2002. Rooting depths, lateral root spreads and below-ground/above-ground allometries of plants in water-limited ecosystems. Journal of Ecology 90: 480-494. DOI: 10.1046/j.1365-2745.2002.00682.x.

Schenk HJ, Jackson RB. 2005. Mapping the global distribution of deep roots in relation to climate and soil characteristics. Geoderma 126: 129-140. DOI: 10.1016/j.geoderma.2004.11.018.

Schilling KE, Kiniry JR. 2007. Estimation of evapotranspiration by reed canarygrass using field observations and model simulations. Journal of Hydrology 337: 356-363. DOI: 10.1016/j.jhydrol.2007.02.003.

Schulze ED, Mooney HA, Sala OE, Jobbagy E, Buchmann N, Bauer G, Canadell J, Jackson RB, Loreti J, Oesterheld M, Ehleringer JR. 1996. Rooting depth, water availability, and vegetation cover along an aridity gradient in Patagonia. Oecologia 108 (3): 503-511.

Scott RL, Shuttleworth WJ, Goodrich DC, Maddock T. 2000. The water use of two dominant vegetation communities in a semi-arid riparian ecosystem. Agricultural and Forest Meteorology 105: 241-256. DOI: 10.1016/S01681923(00)00181-7.

Scott RL, Goodrich DC, Levick LR. 2003. A Gis-Based Management Tool to Quantify Riparian Vegetation Groundwater Use. Proceedings First Interagency Conference on Research in the Watershed, Oct. 27-30, 2003. P. $222-227$.

Scott RL, Huxman TE, Williams DG, Goodrich DC. 2006. Ecohydrological impacts of woody plant encroachment: seasonal patterns of water and carbon dioxide exchange within a semi-arid riparian environment. Global Change Biology 12: 311-324. DOI: 10.1111/j.1365-2486.2005.01093.x.

Serrat-Capdevilla A, Scott RL, Shuttleworth WJ, Valdés JB. 2011. Estimating evapotranspiration under warmer climates: Insights from a semi-arid riparian system. Journal of Hydrology 399: 1-11. DOI:10.1016/j.jhydrol.2010.12.021

Skaggs RW. 1978. A water management model for shallow water table soils. WRRI, University of North Carolina Report No. 134. Cited by Altier et al., 2002.

Snyder KA, Williams DG. 2000. Water sources used by riparian trees varies among stream types on the San Pedro River, Arizona. Agricultural and Forest Meteorology 105: 227-240. DOI: 10.1016/S0168-1923(00)00193-3.

Sparks RE. 1995. Need for ecosystem management of large rivers and their floodplains. BioScience 45: 168-182. Cited by Stromberg, 2001.

Sparovek G, Lima Ranieri S, Gassner A, De Maria I, Schnug E, Ferreira dos Santos F, Joubert A. 2002. A conceptual framework for the definition of the optimal width of riparian forests. Agriculture Ecosystems and Environment 90: 169-175. DOI: 10.1016/S0167-8809(01)00195-5.

Stave J, Oba G, Stenseth NC, Nordal I. 2005. Environmental gradients in the Turkwel riverine forest, Kenya: Hypotheses on dam-induced vegetation change. Forest Ecology and Management 212: 184-198. DOI: 10.1016/j.foreco.2005.03.037.

Stromberg JC, Wilkins SD, Tress JA. 1993. Vegetation-Hydrology Models: implications for management of Prosopis velutina (Velvet Mesquite) Riparian Ecosystems. Ecological Applications 3 (2): 307-314.

Stromberg JC, Tiller R, Richter B. 1996. Effects of Groundwater Decline on Riparian Vegetation of Semi-arid Regions: The San Pedro, Arizona. Ecological Applications 6 (1): 113-131.

Stromberg J. 2001. Restoration of riparian vegetation in the south-western United States: importance of flow regimes and fluvial dynamism. Journal of Arid Environments 49: 17-34. DOI: 10.1006/jare.2001.0833

Tabacchi E, Lambs L, Guilloy H, Planty-Tabacchi A, Muller E, Décamps H. 2000. Impacts of riparian vegetation on hydrological processes. Hydrological Processes 14: 2959-2976. DOI: 10.1002/10991085(200011/12)14:16/17<2959::AID-HYP129>3.0.CO;2-B.

Tabacchi E, Planty-Tabacchi AM, Roques L, Nadal E. 2005. Seed inputs in riparian zones: implications for plant invasion. River Research and Applications 21: 299-313. DOI: 10.1002/rra.848.

Terradas J. 2001. Ecología de la vegetación: de la ecofisiología de las plantas a la dinámica de comunidades y paisajes. España, Ediciones Omega. 703 p. 
Vidon P, Hill A. 2004. Landscape controls on the hydrology of stream riparian zones. Journal of Hydrology 292 (1-4): 210-228. DOI: 10.1016/j.jhydrol.2004.01.005

Webb RH, Leake SA. 2006. Ground-water surface-water interactions and long-term change in riverine riparian vegetation in the southwestern United States. Journal of Hydrology 320: 302-323. DOI: 10.1016/j.jhydrol.2005.07.022.

Welsch DJ. 1991. Riparian forest buffers: function and design for protection and enhancement of water resources. U.S. Dept. of Agriculture, Forest Service, Northeastern Area, State \& Private Forestry, Forest Resources Management. $24 \mathrm{p}$.

Wen L, Saintilan N, Rogers K, Ling J. 2010. Linking river red gum condition to hydrological change at Yanga National Park. Chapter 15. In: Ecosystem Response Modelling in the Murray-Darling Basin. Saintilan N, Overton I. Eds. Csiro Publishing. $448 \mathrm{p}$.

Wild A. 1992. Condiciones del suelo y desarrollo de las plantas según Russell. Translated by P. Urbano Terron y C. Rojo Hernández. Ediciones Mundi-Prensa. $1045 \mathrm{p}$.

Zheng Z, Wang G. 2007. Modeling the dynamic root water uptake and its hydrological impact at the Reserva Jaru site in Amazonia. Journal of Geophysical Research 112: G04012. DOI: 10.1029/2007JG000413. 